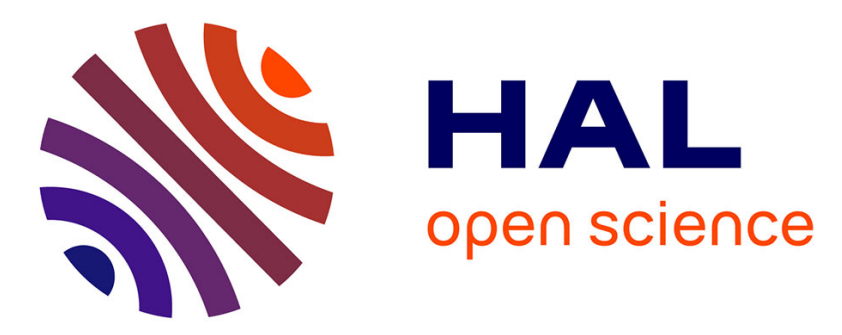

\title{
Hydraulic conductivity and microstructure changes of compacted bentonite/sand mixture during hydration
}

Qiong Wang, Yu-Jun Cui, Anh Minh A.M. Tang, Jean-Dominique Barnichon, Simona Saba, Wei-Min Ye

\section{- To cite this version:}

Qiong Wang, Yu-Jun Cui, Anh Minh A.M. Tang, Jean-Dominique Barnichon, Simona Saba, et al.. Hydraulic conductivity and microstructure changes of compacted bentonite/sand mixture during hydration. Engineering Geology, 2013, 164, pp.67-76. 10.1016/j.enggeo.2013.06.013 . hal-00926873

\section{HAL Id: hal-00926873 \\ https://hal-enpc.archives-ouvertes.fr/hal-00926873}

Submitted on 25 Apr 2018

HAL is a multi-disciplinary open access archive for the deposit and dissemination of scientific research documents, whether they are published or not. The documents may come from teaching and research institutions in France or abroad, or from public or private research centers.
L'archive ouverte pluridisciplinaire HAL, est destinée au dépôt et à la diffusion de documents scientifiques de niveau recherche, publiés ou non, émanant des établissements d'enseignement et de recherche français ou étrangers, des laboratoires publics ou privés. 
1 Hydraulic conductivity and microstructure changes of compacted

$6 \quad{ }^{1}$ Ecole des Ponts ParisTech, Laboratoire Navier/CERMES, France

\section{Corresponding author:}

Prof. Yu-Jun CUI

\section{Ecole des Ponts ParisTech}

6-8 av. Blaise Pascal, Cité Descartes, Champs-sur-Marne

77455 Marne-La-Vallée

France

Telephone : +33164153550

Fax : +33164153562

E-mail : yujun.cui@enpc.fr

\section{bentonite/sand mixture during hydration}

Qiong Wang ${ }^{1}$, Yu-Jun Cui ${ }^{1,3}$, Anh Minh Tang ${ }^{1}$, Jean-Dominique Barnichon ${ }^{2}$, Simona $\mathrm{Saba}^{1}$ Wei-Min $\mathrm{Ye}^{3}$

${ }^{2}$ Institut de Radioprotection et Sureté Nucléaire (IRSN), France

${ }^{3}$ Tongji University, China

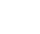

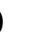

(1)




\section{Abstract:}

Compacted bentonite-based materials are often considered as sealing/backfill materials in deep geological repository for high level radioactive waste. A good understanding of their hydration process is essential as this process is directly related to over-pack corrosion and nuclide migration. In this study, the unsaturated hydraulic properties of MX80 bentonite/sand mixture were characterized by carrying out a series of experiments including water retention test, infiltration test as well as microstructure observation. It was found that with suction decrease under constant volume condition, the hydraulic conductivity decreased followed by an increase after a suction threshold. At suctions higher than $12.6 \mathrm{MPa}$, hydration led to progressive large-pores clogging by exfoliation of clay particles. On the contrary, when saturation was approached (suction lower than 4.2 MPa), the large-pores quantity increased due to the creation of two-dimensional pores. It was also observed that the soil hydraulic conductivity changed following the same tendency as the large-pores quantity during hydration. In other words, water transfer was primarily governed by the network of large-pores.

Keywords: bentonite/sand mixture; suction; constant-volume condition; hydraulic conductivity; microstructure 


\section{INTRODUCTION}

51 Most concepts of deep geological repository for high level radioactive waste are based on the multi-barrier system consisting of the natural barrier (host rock) and engineered barriers (waste container, buffer and sealing elements). One of the most important functions of the engineered barrier is to create a zone of low permeability for separating the high-level radioactive waste from the surrounding environment (Komine, 2010). Bentonite-based materials are often chosen as sealing/backfill materials in this multi-barrier system due to their low permeability, high swelling and high radionuclide retardation capacities (Pusch, 1979; Yong et al., 1986; Villar et al., 2008).

Once emplaced in the repository, the bentonite-based materials start to be hydrated by the pore water infiltrating from the host-rock. These materials absorb water and swell. Firstly, the technological voids are filled up, with a decrease in dry density. Then, the subsequent swelling is restrained by the host rock and swelling pressure develops under constant volume conditions. The hydration under this constant volume condition corresponds to a coupled hydro-mechanical process with involvement of microstructure changes. A proper understanding of this process is essential for well controlling the water transfer-related phenomena as over-pack corrosion, nuclide migration, etc.

A number of studies have been performed to study the water transfer in bentonite-based materials in both saturated state (Kenney et al., 1992; Dixon et al., 
1999; Komine, 2004, etc) and unsaturated state (Börgesson, 2001; Loiseau et al., 2002; Kröhn, 2003a, 2003b; Lemaire et al., 2004; Cui et al., 2008). The saturated hydraulic conductivity has been found to be strongly dependent on the initial dry density (Dixon, 1999; Karnland et al., 2008, etc.). Under unsaturated conditions with suction-dependent water flow, the hydraulic conductivity was often determined using the instantaneous profile method (Daniel, 1982). Following this method, Cui et al. (2008) investigated the unsaturated hydraulic conductivity of the Kunigel bentonite/sand mixture and observed that with suction decrease under constant volume conditions, the hydraulic conductivity decreases followed by an increase after certain suction threshold. Ye et al. (2009) obtained similar results on GMZ bentonite. Thomas et al. (2003) and Villar et al. (2005) also pointed out that, in expansive materials, hydraulic conductivity decreases with the increase in degree of saturation, due to microstructural modifications. This is different from the common results showing that the hydraulic conductivity of unsaturated soils increases with suction decrease (van Genuchten, 1980; Fredlund and Rahardjo, 1993). The particular trend observed for bentonite-based materials adds a degree of complexity when dealing with the long term behaviour of these materials. Without considering this phenomenon, the water transfer in bentonite-based materials will be over-estimated. Thus, it is of great importance to go in depth of this phenomenon by considering the coupled hydro-mechanic changes during the hydration process.

If the phenomenon of the particular hydraulic conductivity changes with suction decrease for bentonite-based materials was evidenced experimentally (Cui et al., 2008; 
Ye et al.; 2009), the explanation has been not yet confirmed by microstructure analysis. The present study aims at completing this lack by investigating the hydraulic properties of a compacted bentonite-sand mixture and the microstructure changes during the hydration process. Infiltration test and water retention test were first carried out under constant volume conditions allowing the determination of hydraulic conductivity by the instantaneous profile method. The study was then completed with the microstructure observation allowing analysing the effect of microstructure change on the variations of hydraulic conductivity. All tests were carried out at constant ambient temperature $\left(20 \pm 1^{\circ} \mathrm{C}\right)$, and the effect of temperature was not considered in this study.

\section{MATERIALS AND METHODS}

\subsection{Materials and samples preparation}

The soil studied is a mixture of MX80 bentonite and quartz sand with a proportion of 70/30 in dry mass. The bentonite is from Wyoming, USA, with a high content of montmorillonite (80\%). It has a liquid limit of $575 \%$, a plastic limit of $53 \%$ and a unit mass of $2.77 \mathrm{Mg} / \mathrm{m}^{3}$. The cation exchange capacity (CEC) is $76 \mathrm{meq} / 100 \mathrm{~g}$ (83\% of $\mathrm{Na}^{+}$). The grain size distribution (Figure 1) determined by hydrometer (French standard AFNOR NF P94-057) on deflocculated clay shows that the fraction of clay-size particles $(<2 \mu \mathrm{m})$ is $84 \%$.

The sand used in the mixture was from Eure and Loire (France), with a unit mass of sand grains of $2.65 \mathrm{Mg} / \mathrm{m}^{3}$. It was sieved at $2 \mathrm{~mm}$ prior to being mixed with the 
114 bentonite. Figure 1 shows the grains size distribution curve determined by the dry

115 sieving method (AFNOR NF P94-056). The curve for sand is characterized by a

116 uniformity coefficient $C_{u}$ of 1.60 and a $D_{50}$ close to $0.6 \mathrm{~mm}$. This curve is close to that

117 of bentonite powder obtained by "dry" sieving (see in Figure 1).

118 Synthetic water having similar chemical composition to that of the pore water of the

119 Callovo-Oxfordian claystone (TDS = $5.7 \mathrm{~g} / \mathrm{L}$ ) from the ANDRA Underground

120 Research Laboratory (URL) in Bure (France) was used for the infiltration test (Table

121 1). For the preparation of the synthetic water, the chemical components in powder 122 were mixed with distilled water using a magnetic stirrer until full dissolution.

123 For the samples preparation, the bentontie powder has a hydroscopic water content of $124 \quad 12.2 \%$ was carefully mixed with dry sand (70\% bentonite $-30 \%$ sand in mass) giving 125 a mixture at a water content of $8.5 \%$. The mixture powder was then put into a 126 hermetic container connected to a vapor circulation system containing free water 127 (100\% relative humidity), so as to reach a target water content of $11.0 \%$. The grain 128 size distribution curve of the mixture powder is presented in Figure 1. It shows a well 129 graded distribution around a mean diameter of $0.9 \mathrm{~mm}$.

130 The soil specimens for both the infiltration and water retention tests were obtained by 131 compaction of the bentonite/sand mixture powder at its water content of $11.0 \%$. A 132 given quantity of the mixture was placed in a metallic mould and statically compacted 133 to a dry density of $1.67 \mathrm{Mg} / \mathrm{m}^{3}$. The initial suction of the compacted samples was 134 about $65 \mathrm{MPa}$ (measured using a relative humidity sensor after compaction). For the infiltration test, the specimen (250-mm long and $50 \mathrm{~mm}$ in diameter) was compacted 
in 5 layers of 50-mm thickness each.

\subsection{Experimental method}

The hydraulic conductivity of the unsaturated bentonite/sand mixture was determined using the instantaneous profile method, which requires both suction and volumetric water content profiles (Daniel, 1982; Cui et al., 2008; Ye et al., 2009). The suction profile (corresponding to the total suction) was obtained by monitoring the relative humidity (RH) changes in an infiltration test, whereas the volumetric water content profile was deduced from the water retention curve determined separately.

\subsubsection{Infiltration test}

The hydration cell used for the infiltration test is presented in Figure 2. After compaction, the soil specimen (50 $\mathrm{mm}$ in diameter and $250-\mathrm{mm}$ long) was carefully introduced into the cylindrical cell (50 $\mathrm{mm}$ in inner diameter) with the ends of the two cells jointed together. The hydration cell is made of stainless steel, which hindered any lateral volume changes. Four relative humidity $(\mathrm{RH})$ sensors were installed every $50 \mathrm{~mm}$ along the sample $(\mathrm{h}=50,100,150,200 \mathrm{~mm}$ from the wetting end $)$ through the ports in the wall of the cell. The RH sensor consists of a unique capacitive sensor element for RH measurement and a stainless steel shell (12 $\mathrm{mm}$ in external diameter) for protecting the sensors from deformation and corrosions. Two ends of the cell were tightly closed by metallic discs of $40 \mathrm{~mm}$ thickness each. Water supply was done at the atmospheric pressure through the water inlets in the bottom base, which was connected to burettes. The top cover has an outlet for air expulsion. To avoid water 
evaporation, a deflated balloon-shaped membrane was used to cover the air outlet. The air in the membrane was released regularly in order to keep an air pressure close to the atmospheric one. The water volume injected into the sample was also measured during the test by monitoring the water level in the burettes.

At the end of the infiltration test, the sample was extruded by pushing the top side, about $12 \mathrm{MPa}$ pressure was applied for this purpose. Several small specimens at different positions along the column were taken for the water content and dry density determinations. The water content of the sample was measured by oven drying, while the dry density was determined based on the fluid displacement technique (see Head, 1980, Geiser, 1999) using an immiscible oil Kerdane (with a density of 0.791 at $\left.20^{\circ} \mathrm{C}\right)$.

\subsubsection{Water retention curve}

The water retention curve of the bentonite/sand mixture under constant volume condition was determined by controlling the suction using both the vapour equilibrium technique (for suctions higher than 4.2 MPa) and osmotic technique (for suctions of 1 and $0.1 \mathrm{MPa}$ ). It is worth noting that the vapour equilibrium technique controls total suction whereas the osmotic technique controls matric suction (see Delage 1998a; Delage and Cui, 2008; Blatz et al.; 2008 for more detailed). The zero suction was imposed by injecting the synthetic water (Table 1) into the sample.

The compacted sample $(50 \mathrm{~mm}$ in diameter and $5 \mathrm{~mm}$ in height) was placed in a stainless steel cell. Two porous disks were put at both sides of the sample allowing 
vapour or water flow. To apply the osmotic technique, a semi-permeable membrane was placed between the porous stone and the soil sample (Figure 3a), the whole was then sandwiched between two perforated discs and immerged in a PEG 20000 (Polyethylene Glycol) solution at a concentration corresponding to the required suction (see Table 2). Several drops of penicillin were added in the solution to prevent from attack of bacteria. To apply suction with the vapour equilibrium technique, the sample sandwiched between two porous stones was installed between two external plates with valves (Figure $3 b$ ) that were connected to a device containing a saturated salt solution for relative humidity control (see Wang et al., 2012 for more details). Following this technique, 2-4 weeks was required to reach the equilibrium (Marcial, 2003; Tang \& Cui, 2005). However, the equilibrium time was much shorter for the osmotic technique as it allows liquid water exchanges between the soil sample and the PEG solution (Blatz et al., 2008). In this study, the equilibration time was extended to 2 months for both the vapour equilibrium technique and osmotic technique and the water content of all samples was determined by weighing at the end.

All water retention tests performed and the solutions used for suction control are presented in Table 2. As shrinkage may occur upon drying, it was not possible to control sample volumes along drying paths. Thus, only the wetting curve was determined under restrained-swell conditions. This was enough for the purpose of hydraulic conductivity determination based on the infiltration test under constant volume conditions. 


\subsubsection{Microstructure observation}

Mercury Intrusion Porosity (MIP) and Scanning Electron Microscope (SEM) tests were carried out on freeze-dried samples, which had been equilibrated at different suctions under constant volume conditions. The suction values considered ranged from $65 \mathrm{MPa}$ (as-compacted state) to zero (saturated state). For as-compacted samples, it was cut to small slices and freeze-dried (see Delage \& Lefevbre, 1984; Cui et al., 2002., Delage et al., 2006; Tang et al., 2011 for more details). Samples for other suctions were taken from the water retention test under constant volume conditions

(Table 2 for details). Each sample was cut to two parts, one for the preparation of samples for the microstructure observation and another for water content determination by weighing (for water retention curve).

\section{EXPERIMENTAL RESULTS}

Figure 4 depicts the water retention curve (suction versus the gravimetric water content) obtained along the wetting path under constant-volume conditions. In the plane of gravimetric water content versus suction (Figure 4), a bi-linear water retention curve was obtained: water content increases linearly with suction decrease when this latter is higher than $1 \mathrm{MPa}$; at lower suctions the water content remains constant and the water retention curve is almost horizontal. The inflexion of the WRC (1 MPa) can be considered as the air-entry value of the sample.

At the end of the infiltration test, the sample was removed by pushing it from the top. 
The water content and dry density along the column were determined and shown in Figure 5. As expected, the water content decreased with increasing distance from the wetting end. Regarding the dry density distribution, a lower dry density than at the 222 initial state $\left(1.62-1.65 \mathrm{Mg} / \mathrm{m}^{3}\right.$ against $\left.1.67 \mathrm{Mg} / \mathrm{m}^{3}\right)$ was obtained in the near wetting end zone $(\mathrm{h}=0-40 \mathrm{~mm})$; a dry density close to the initial one $\left(1.67-1.68 \mathrm{Mg} / \mathrm{m}^{3}\right.$ against $1.67 \mathrm{Mg} / \mathrm{m}^{3}$ ) was obtained in the middle zone $(\mathrm{h}=50-150 \mathrm{~mm})$; in the upper zone $\left(\mathrm{h}=200-250 \mathrm{~mm}\right.$ ), a significant dry density increase up to $1.73 \mathrm{Mg} / \mathrm{m}^{3}$ was 226 identified.

During the infiltration test, $\mathrm{RH}$ changes over time were monitored and plotted in Figure 6 for all measurement positions ( $h=50,100,150$ and $200 \mathrm{~mm}$ ). The initial RH was $62 \pm 1 \%$ corresponding to a suction of $64.5 \pm 1.5 \mathrm{MPa}$. Once the infiltration started, the value of the $\mathrm{RH}$ at $h=50 \mathrm{~mm}$ increased rapidly and reached $90 \%$ after

$231500 \mathrm{~h}$, then increased gradually to $98.30 \%$ after $1900 \mathrm{~h}$. The value of the sensors at $h$

$232=100,150$ and $200 \mathrm{~mm}$ started to increase after about $200 \mathrm{~h}, 500 \mathrm{~h}$ and $1900 \mathrm{~h}$ respectively. The larger the distance from the wetting end the lower the increasing rate 234 of RH.

235 The total suction $(s)$ was then calculated from RH value using Kelvin's law:

$$
s=-\left(\rho_{w} R T / M_{w}\right) \ln (R H / 100)
$$

237 where $\rho_{w}$ is the water unit mass $\left(1 \mathrm{Mg} / \mathrm{m}^{3}\right) ; R$ is the universal (molar) gas constant $238(8.31432 \mathrm{~J} / \mathrm{mol} \mathrm{K}) ; T$ is the absolute temperature $(\mathrm{K})$, equal to $(273.15+20){ }^{\circ} \mathrm{C}$ in this study; $M_{w}$ is the molecular mass of water vapour $(18.016 \mathrm{~kg} / \mathrm{kmol})$. 
Figure 7 depicts the suction isochrones for every $400 \mathrm{~h}$. Note that the suction value at

$241 \mathrm{~h}=250 \mathrm{~mm}$ was not monitored and it was estimated by linearly extending the curves

242 between $h=150 \mathrm{~mm}$ and $\mathrm{h}=200 \mathrm{~mm}$. At $\mathrm{t}=0$, the initial suction of the sample was

243 quite homogeneous, with a mean value of $64.5 \pm 1.5 \mathrm{MPa}$. It was supposed that after

244 starting the infiltration, the suction at the wetting face $h=0 \mathrm{~mm}$ decreased rapidly to

245 zero. The total suction at $\mathrm{h}=50 \mathrm{~mm}$ decreased to $2.37 \mathrm{MPa}$ at $\mathrm{t}=2200 \mathrm{~h}$ while the

246 total suction at $\mathrm{h}=200 \mathrm{~mm}$ started to decrease at $\mathrm{t}=1900 \mathrm{~h}$, and remained high $(\mathrm{s}=$

$247 \quad 33.84 \mathrm{MPa})$ at $\mathrm{t}=6000 \mathrm{~h}$.

248 Based on the suction profiles (Figure 7), the hydraulic gradients (i) and water fluxes

$249(q)$ at each measurement section $(h)$ and time $(t)$ were deduced following the methods

250 shown in Figure 8. The hydraulic gradients were calculated as the tangent of suction

251 profiles ( $s$ and $h$ are expressed in $\mathrm{m}$ ) as indicated in Figure 8a and the water fluxes

252 were determined by integrating the difference in the volumetric water content profiles

253 at a time interval $(\Delta t)$ as indicated in Figure $8 \mathrm{~b}$.

254 To calculate the water flux, the volumetric water content of the mixture was deduced

255 from the total suction using the water retention curve obtained at constant-volume

256 conditions (Figure 4). As the suction measured by RH sensors in the infiltration test

257 ranges from 2.37 $\mathrm{MPa}$ to $65 \mathrm{MPa}$, Eq. 2 (see also Figure 4) was used to calculate the

258 gravimetric water content from suction, and the volumetric water content $(\theta)$ can be

259 then calculated using Eq.3:

$$
w=-7.261 \log (\mathrm{s})+24.102
$$

$$
\theta=w \rho_{d} / \rho_{w}
$$


where, $\rho_{d}$ is assumed to be constant $\left(1.67 \mathrm{Mg} / \mathrm{m}^{3}\right)$ during infiltration under constant volume conditions.

In order to verify the validity of these calculations, the total volume of water passing through each section was calculated from the volumetric water content profiles. The sum of these volumes from $\mathrm{h}=0 \mathrm{~mm}$ to $\mathrm{h}=250 \mathrm{~mm}$ corresponds to the volume of water absorbed by the soil specimen during infiltration. Figure 9 shows the comparison between the injected volume of water and that estimated from the water content profiles. It can be observed that there is a good agreement between the measured and calculated values, confirming the validity of the analyses performed.

Using the suction profiles presented in Figure 7, the hydraulic gradient $(i)$ and water fluxes $(q)$ at the four measurement sections $h=50 \mathrm{~mm}, 100 \mathrm{~mm}, 150 \mathrm{~mm}$ and 200 $\mathrm{mm}$ for each $100 \mathrm{~h}$ were obtained, and used to calculate the hydraulic conductivity by applying Darcy's law (Eq.4). The hydraulic conductivity determined is plotted versus suction in Figure 10. It can be seen that at different measurement sections different relationships were obtained.

$$
k_{w}=-\frac{1}{A} \cdot \frac{q}{\frac{1}{2}\left(i_{t}+i_{t+\Delta t}\right)}
$$

where, $k_{w}$ is the hydraulic conductivity; $i_{t}$ and $i_{t+\Delta t}$ are the hydraulic gradients at instant $t$ and $t+\Delta t$, respectively.

The pore size distribution curves for suctions ranging from $65 \mathrm{MPa}$ (initial state) to 12.6 MPa are presented in Figure 11a and Figure 11b. It was observed in Figure 11a 
that the final values of the intruded mercury void ratio $\left(e_{m i}\right)$ were lower than the global soil void ratio $(e=0.63)$. Moreover, the amount of non-intruded porosity $\left(e_{m i}=\right.$ 0.47 in the initial state) decreased with suction decrease. From the derivative curves (Figure 11b), a typical bimodal porosity was identified in the initial state $\left(\rho_{d}=1.67\right.$ $\mathrm{Mg} / \mathrm{m}^{3}, \mathrm{~s}=65 \mathrm{MPa}$ ), and two pore groups can be defined: small-pores having a mean size of $0.02 \mu \mathrm{m}$ and large-pores having a mean size of $50 \mu \mathrm{m}$. Following the classification detailed in Stepkowska (1990) and Villar et al. (2012), these two pore families correspond to the categories of mesopores $(0.002-0.05 \mu \mathrm{m})$ and macropores (> $0.05 \mu \mathrm{m}$ ), respectively. The application of $38 \mathrm{MPa}$ suction resulted in significant decrease of large-pores quantity (about 10\%), and little changes in small-pores (Figure 11b). However, no obvious further changes in both the large-pores and small-pores can be observed for the subsequent decrease of suction (38 - 24.8 - 12.6 $\mathrm{MPa})$.

Figures $11 \mathrm{c}$ and $11 \mathrm{~d}$ show the curve for 4.2, 1 and $0 \mathrm{MPa}$ suction, lower values of non-intruded void ratio $e_{m i}$ were also obtained compared to the global void ratio of the soil (Figure 11c). However, it was found that the intruded porosity at these suctions was slightly higher than that in the initial state $\left(s=65 \mathrm{MPa}, e_{m i}=0.47\right)$. From the derivative curves (Figure 11d), it was clearly seen that this increased intruded porosity corresponded to the difference in large-pores volume, as the small-pores volume decreased with decreasing suction. Moreover, a third pore family (with pore size of 0.1-2 $\mu \mathrm{m})$ appeared for the saturated sample. 
The pore size distribution analyse was completed using the SEM technique (Figure 12). The photos were taken at two scales which focused on the behaviour of mixture $(1250 \times 1000 \mu \mathrm{m})$ and bentonite aggregates $(25 \times 20 \mu \mathrm{m})$, respectively. The sand grains cannot be identified in the photos at lower magnification (picture size of $1250 \mathrm{x}$ $1000 \mu \mathrm{m})$. The photograph taken at the initial state (s = $65 \mathrm{MPa}$ ) clearly shows the large-pores with a maximum diameter of about $100 \mu \mathrm{m}$ (Figure 12a), which is in agreement with the MIP results from Figure 11a. Figure 12b shows that the aggregates were densely assembled. The small-pores observed in the MIP test $(0.02$ $\mu \mathrm{m})$ cannot be detected by the SEM technique. Comparison of the photographs of 38 $\mathrm{MPa}$ suction (Figure 12d) and $65 \mathrm{MPa}$ suction (Figure 12b) shows that the clay particles exfoliation occurred when suction decreased. The photographs at saturated state (Figure 12e and 12f) show that the large-pores observed at higher suctions (Figure 12a and 12c) were filled by the swollen bentonite; however, there are fissure-like (with very large aspects ratio) 2-dimensional pores (2-D pores) which correspond to the pore group with a mean diameter of $50 \mu \mathrm{m}$ and $1 \mu \mathrm{m}$ observed in Figure 11d. Audiguier et al. (2008) observed similar 2-D pores of a diameter between 0.1 and $1 \mu \mathrm{m}$ in a natural clay after free swelling.

\section{INTERPRETATION AND DISCUSSION}

After the infiltration test, a decrease of dry density was observed in the lower part $(\mathrm{h}=$ 0-40 mm), a dry density close to the initial was obtained in the middle zone $(\mathrm{h}=$ 50-150 mm). Several authors (Lemaire et al., 2004; Kröhn, 2003b, 2004; Villar et al., 
2008) reported that swelling leads to a displacement of clay particles in the near wetting end zone, and thus to a significant decrease of dry density. This in turn causes compaction of the bentonite in the still dry parts. This was obviously not the case in this study because the resulting compaction in the middle zone was not noticeable: the value of dry density remained the same after the test. Thereby, the decrease of dry density in the near wetting end zone may probably due to the soil rebounding due to the release of swelling pressure. The limited compaction by soil swelling pressure can be also explained by the fact that the compaction pressure applied for sample preparation was about $12 \mathrm{MPa}$, much higher that the soil swelling pressure estimated at $3 \mathrm{MPa}$ at $1.67 \mathrm{Mg} / \mathrm{m}^{3}$ dry density (see Wang et al. 2013). As far as the upper part $(200-250 \mathrm{~mm})$ is concerned, the significant increase of dry density is rather related to the sample removal. As described previously, the sample was extruded by pushing the top side with a pressure as high as $12 \mathrm{MPa}$. This pressure was almost the same as the pressure applied for the sample compaction. If we consider a yield stress of $12 \mathrm{MPa}$ for the sample at its initial state, the value must decrease upon hydration. Therefore, significant compaction can be expected during sample extrusion. However, this compaction was limited to the upper part because of the contribution of the friction between the sample and the metallic column. Kröhn $(2003 \mathrm{~b}, 2004)$ performed a laboratory infiltration test on MX80 bentonite with an initial dry density of 1.50 $\mathrm{Mg} / \mathrm{m}^{3}$ and observed similar phenomenon: significant decrease of dry density occurred in the area near the wetting end (20 mm for a sample of $100 \mathrm{~mm}$ long); no-noticeable changes occurred in the remaining part. In addition, all density changes 
took place within the first four days, with no time dependence (over 189 days).

Thereby, they considered that the assumption of no migration of bentonite particles in the specimen is a good approximation except for the first few millimeters (Kröhn, 2004). Therefore, in the test conditions adopted in the present work, it is believed that the error was very limited when determining the hydraulic conductivity by taking the mean value of dry density $\left(1.67 \mathrm{Mg} / \mathrm{m}^{3}\right)$.

From the shape of the suction isochrones shown in Figure 7, it can be observed that suction changes mainly occurred in the lower part of the sample below $100 \mathrm{~mm}$, and in the upper part limited changes were identified. This is in agreement with the water content distribution curve (Figure 5a), where much more change near the wetting end was observed. As noted by Delage et al. (1998a, b) and Ye et al. (2009), this phenomenon could be explained by separating the liquid water transfer from the water vapour diffusion: in the zone near the wetting face, the water transfer involves mainly the liquid water; by contrast, water vapour diffusion prevails in the zone far from the wetting face. In fact, infiltration tests performed by Delage et al. (1998a, b) showed almost vertical suction profiles in all time within the part beyond $50 \mathrm{~mm}$ from the wetting face. As the suction was deduced from the measured relative humidity, they concluded that at the upper part beyond $50 \mathrm{~mm}$, the water transfer was mainly governed by vapour diffusion. The less vertical suction profiles in the present work suggest a relatively less prevailing vapour transfer than that in the case of Delage et al (1998a, b). 
By applying Darcy's law, different relationships between hydraulic conductivity and suction were obtained at different measurement sections (Figure 10). As reported by Loiseau et al. (2002), Cui et al., (2008) on the Kunigel/sand mixture and Marcial (2003) on the pure MX80 bentonite, this phenomenon is related to the effect of hydraulic gradient. In general, when experimentally determining the hydraulic conductivity based on Darcy's law, a linear relationship between water flow rate $(q)$ and hydraulic gradient (i) is obtained. However, non-linear relationships are often observed for clayey soils (Lutz \& Kemper, 1959; Miller \& Low, 1963; Zou, 1996), and there is a "critical gradient" below which flow occurs in non-Darcian mode (Yong and Warkentin, 1975; Dixon et al., 1987). This can be explained by the high energy of the water adsorbed in clays, which increases with the clay fraction and activity (Dixon et al., 1987). When the hydraulic gradient increases, this energy is overcome locally and the adsorbed water can be mobilised. For soils containing highly active clay minerals such as smectite in this study, this critical gradient effect can be significant leading to different $k-s$ relationships obtained at different measurement sections.

For clarifying this effect, the water fluxes $(q)$ and hydraulic gradient $(i)$ for each suction level (suction from 62 to $32 \mathrm{MPa}$ ) are plotted in Figure 13. Bi-linear relationships can be observed for each suction value, indicating existence of "critical gradients", their values ranging from 8000 to 38000 . To apply Darcy's law, the water flow was considered only when the linear segment at higher water flux was reached (details about this method can be found in Dixon et al., 1992). 
Considering the critical gradient effect (Figure 13), the hydraulic conductivity was corrected and shown in Figure 14. A unique relationship was obtained between hydraulic conductivity and suction, independent of the measurement sections. In Figure 14, the hydraulic conductivity determined by Karnland et al. (2008) for the same material at the same dry density $\left(1.67 \mathrm{Mg} / \mathrm{m}^{3}\right)$ under saturated state is also presented: a much higher value of $10^{-13} \mathrm{~m} / \mathrm{s}$ was observed. Unlike the non swelling soils for which the hydraulic conductivity is increasing upon wetting, a "U-shape" relationship was observed: the hydraulic conductivity decreased when suction decreased from 65 to about $15 \mathrm{MPa}$, then increased for further suction decrease. Similar observations were made on the Kunigel-V1/sand mixture (JNC, 2000; Cui et al., 2008) and GMZ bentonite (Ye et al., 2009). As explained by Cui et al. (2008) and Ye et al. (2009), in the beginning water transfer was primarily governed by the network of large-pores, which were progressively clogged by the expanding hydrated aggregates, leading to the hydraulic conductivity decrease. When the large-pores clogging ended and water transfer was controlled by the suction gradient, the common hydraulic conductivity increase with suction decrease was observed.

It was observed in Figure 11a that the intruded mercury void ratio $\left(e_{m i}\right)$ were lower than the global soil void ratio $(e=0.63)$. This can be explained by the limited pressure range of the MIP technique: for the high-plasticity soils, there is a significant pore volume (entrance diameter smaller than $6 \mathrm{~nm}$ ) that the mercury could not penetrate to (Lloret et al., 2003; Delage et al., 2006). Comparison of the curves at different suctions shows that with decreasing suction (65-38-24.9-12.6 MPa), the amount of 
411 phenomenon and explained by the interaction between large- and small-pores: during

412 suction decrease under constant-volume conditions the size of non-intruded pores

413 increased with increasing interlayer space, while the large-pores were filled by small

414 clay particles.

415 Figure $11 \mathrm{~b}$ showed that suction decrease did not change the small-pores family,

416 whereas a decrease of large-pores quantity was observed - it was significant when

417 suction decreased from $65 \mathrm{MPa}$ to $38 \mathrm{MPa}(10 \%)$ and much less (3\%) for the

418 subsequent suction decrease $(38-24.8-12.6 \mathrm{MPa})$. This confirms the previous

419 conclusion that during suction decrease the large-pores were clogged (although at

420 different rate) by the invasion of exfoliated clay particles whose interlaminar distance

421 increases upon saturation. This phenomenon could also be identified in the SEM

422 photograph with high magnification for $38 \mathrm{MPa}$ suction (Figure 12d).

423 For suction lower than 4.2 MPa (Figure 11c), a lower value of $e_{m i}$ was also obtained 424 compared to the global void ratio $(e=0.63)$. However, the intruded porosity at these 425 suctions (4.2, 1 and $0 \mathrm{MPa})$ was slightly higher than that in the initial state $(s=65$ $\left.426 \mathrm{MPa}, e_{m i}=0.47\right)$. This phenomenon can be attributed to the larger pore quantity of the 427 pore group having a mean size of $50 \mu \mathrm{m}$ (for 4.2 and $1 \mathrm{MPa}$ suction) and $1 \mu \mathrm{m}$ (for 428 zero suction) compared with the initial state (Figure 11d). These two pores groups 429 were identified as 2-D pores of about 50 and $1 \mu \mathrm{m}$ diameter for the saturated sample 430 in Figure 12e and 12f, respectively. Audiguier et al. (2008) explained the formation of 
the 2-D pores by the division of clay particles within the aggregates due to swelling. Moreover, the small deformation induced by the release of swelling pressure before freeze-drying may also play a role in the large-pores quantity increase. However, this slight effect could not be identified by the current technique of samples preparation, and new methods without stress state changes are needed to obtain more accurate microstructure observations.

It appeared that the small-pores changed only when the saturation was approached (1 $\mathrm{MPa}$ and $0 \mathrm{MPa}$ in Figure 11 and Figure 12). This phenomenon is in agreement with the conclusion by Cui et al. (2002) for the Kunigel clay/sand mixture: when water infiltrated into the soil, the hydration of clay aggregates hydration started first on the surface giving rise to the clay particles exfoliation and resulting in the clogging of large-pores, whereas the small-pores remained almost un-affected; the small-pores started to change only when the water saturation was approached (suction lower than $9 \mathrm{MPa}$. When saturation was reached, the clay aggregates disappeared (Figure 12f) and a new pore family of about $1 \mu \mathrm{m}$ diameter was formed, visible from both MIP and SEM tests. The small-pores seemed to be compressed by the swelling pressure, whereas 2-D pores of $1 \mu \mathrm{m}$ in diameter appeared due to the division of clay particles within the aggregates (Saiyouri et al., 2000).

In order to quantify the suction effect on the large-pores, a large-pores radius larger than $2 \mu \mathrm{m}$ was considered based on the curves in Figure 11where it can be observed that the proportion of pores larger than $2 \mu \mathrm{m}$ changed with decreasing suction. Using 
this limit value that separates large-pores from small-pores, the void ratio corresponding to the large-pores was derived from the cumulative curves (Figure 11).

The relationship between the calculated large-pore void ratio $\left(e_{L}\right)$ and applied suction are presented in Figure 15. It can be seen that the large-pores quantity was progressively reduced with decreasing suction in the range of 65 to $12.6 \mathrm{MPa}$ (zone I).

However, the subsequently decrease of suction to $4.2 \mathrm{MPa}$ led to an increase of large-pores quantity. This can be explained by the creation of the 2-D pores described above; a significant decrease followed when suction decreased from $1 \mathrm{MPa}$ to zero (zone II).

It is interesting to note that if we relate the large-pore changes (Figure 15) to the hydraulic conductivity changes (Figure 14), it seems that the hydraulic conductivity changed following the same trend as the large-pores quantity during hydration. In other words, water transfer was primarily governed by the network of large-pores in the full suction range, but not controlled by the suction gradient in the lower suction range as mentioned above. The large-pores decreased progressively in quantity due to the clay particles exfoliation occurred on the aggregates surface in the suction range from 65 to $12.6 \mathrm{MPa}$, leading to a decrease of hydraulic conductivity. When saturation was approached (4.2 - $1 \mathrm{MPa})$, water transfers through the 2-D pores appeared, leading to an increase in hydraulic conductivity; in saturated state the value can reach as high as $10^{-13} \mathrm{~m} / \mathrm{s}$ as reported by Karnland et al. (2008). It should be noted that after saturation, the hydraulic conductivity has been found to be time dependent (Loiseau et al., 2002; Cui et al., 2008). It decreased with time due to the re-organization of 
474 microstructure over time in the soil sample. After saturation, water in the 475 inter-aggregate pores is not necessarily in equilibrium with the water inside the aggregates in terms of water potential. Thus the water re-distribution occurred inside

477 the soil, leading to a uniform microstructure in long term (Stroes-Gascoyne et al., 478 2010).

\section{CONCLUSION}

The hydraulic properties of a compacted bentonite-sand mixture were investigated in the laboratory by carrying out water retention test and infiltration test as well as the microstructure observation. The results obtained allowed relating the variation of hydraulic conductivity to the microstructure changes.

During suction decrease (suction higher than 12.6 MPa) the large-pores were clogged when saturation was approached (suction lower than 4.2 MPa) large-pores quantity increased again due to the appearance of 2-D pores. The small-pores changed only when saturation was approached.

With suction decrease under constant volume condition, the hydraulic conductivity

490 decreased followed by an increase after certain suction threshold. This change 491 followed the same tendency as the large-pores quantity. In other words, water transfer 492 was primarily governed by the network of large-pores. Over time, the hydraulic conductivity is expected to decrease due to the water re-distribution among different 
pore families that leads to a uniform microstructure in long term.

\section{ACKNOWLEDGEMENTS}

The work was conducted in the framework of the SEALEX project of IRSN and the PHC Cai Yuanpei project (24077QE). The support of the National Nature Science Foundation of China (41030748) and that of the China Scholarship Council (CSC) are also greatly acknowledged.

\section{REFERENCES}

AFNOR, 1992. AFNOR NF P94-057, Soils: investingation and testing. Granulometric analysis. Hydrometer method. Association Francaise de Normalisation. France.

AFNOR, 1996. AFNOR NF P94-056, Soils: investigation and testing. Granulometric analysis. Dry sieving method after washing. Association Francaise de Normalisation. France.

Audiguier, M., Geremew, Z., Cojean, R., 2008. Relations enter les microstructures de deux sols argileux de la région parisienne et leur sensibilité au retrait gonflement. SEC2008, Paris, France, 1-3 sept. Editions du LCPC.2008: 235-243.

Blatz, J.A., Cui, Y. J., Oldecop. L., 2008. Vapour Equilibrium and Osmotic Technique for Suction Control. Geotech Geol Eng (2008) 26:661-673.

Börgesson, L., Chijimatsu, M., Fujita, T., Nguyen, T.S., Rutqvist, J., Jing, L., 2001. Thermo-hydro-mechanical characterisation of bentonite-base buffer material by laboratory tests and numerical back analyses. International Journal of Rock Mechanics \& Mining Sciences 38, 95-104.

Cui, Y. J., Loiseau, C., Delage, P., 2002. Microstructure changes of a confined swelling soil due to suction controlled hydration Unsaturated soils: proceedings of the Third International Conference on Unsaturated Soils, UNSAT 2002, 10-13 March 2002, Recife, Brazil, 593.

Cui, Y.J., Tang, A..M., Loiseau, C., Delage, P., 2008. Determining the unsaturated hydraulic conductivity of a compacted sand-bentonite mixture under constant-volume and free-swell conditions. Physics and Chemistry of the Earth, Parts A/B/C, 33(Supplement 1):S462 - S471.

Daniel, D.E., 1982. Measurement of hydraulic conductivity of unsaturated soils with thermocouple psychrometers. Soil Science Society of America Journal 20 (6):1125-1129.

Delage, P., Lefebvre, G., 1984. Study of the structure of a sensitive Champlain clay and its evolution during consolidation. Canadian Geotechnical Journal 21 (1), 21-35. 
Delage P., Howat M., Cui Y.J. 1998a, The relationship between suction and swelling properties in a heavily compacted unsaturated clay. Eng Geol 50(1-2):31-48

Delage, P., Cui, Y.J., Yahia-Aissa, M., De Laure, E., 1998b. On the unsaturated hydraulic conductivity of a dense compacted bentonite. Proc. of Unsat'98, Beijing, vol. 1,pp. 344-349.

Delage, P., Marcial, D., Cui, Y.J., Ruiz, X., 2006. Ageing effects in a compacted bentonite: a microstructure approach. Géotechnique 56 (5), 291-304.

Delage P.,Cui Y.J., 2008, An evaluation of the osmotic method of controlling suction, Geomechanics and Geoengineering, 3(1):1-11

Dixon, D.A., Cheung, S.C.H., Gray, M.N., Davidson, B.C., 1987. The hydraulic conductivity of dense clay soils. Proc. 40th Canadian Geotechnical Conference, Regina, Saskachewan - Canada, pp. 389-396.

Dixon, D.A., Gray, M.N., Hnatiw, D., 1992. Critical gradients and pressures in dense swelling clays. Canadian Geotechnical Journal 29 (6), 1113-1119.

Dixon, D.A., Graham, J., Gray, M.N., 1999. Hydraulic conductivity of clays in confined tests under low hydraulic gradients. Canadian Geotechnical Journal 36 (5), 815- 825.

Fredlund, D.G., Rahardjo, H., 1993. Soil mechanics for unsaturated soils. John Wiley and Sons, New York

GEISER F. 1999, Comportement mécanique d'un limon non saturé:étude expérimentale et modélisation constitutive[D]. Switzerland: Thesis, Ecole Polytechnique Fédérale deLausanne, EPFL.

HEAD K H. 1980, Manual of soil laboratory testing, volume 1: soil classification and compaction tests[M]. London: Pentech Press.

JNC, 2000. H12: Project to establish the scientific and technical basis for HLW disposal in Japan, report TN1410 2000-001, Tokai-Mura.

Karnland, O., Nilsson, U., Weber, H., and Wersin, P., 2008. Sealing ability of Wyoming bentonite pellets foreseen as buffer material-Laboratory results. Physics and Chemistry of the Earth, Parts A/B/C, 33:S472-S475.

Kenney, T.C., van Veen, W.A., Swallow, M.A.., Sungaila, M.A., 1992. Hydraulic conductivity of compacted bentonite-sand mixtures. Canadian Geotechnical Journal 29 (3): 364-374.

Komine, H., 2004. Simplified evaluation on hydraulic conductivities of sand-bentonite mixture backfill. Applied Clay Science 26 (1-4), 13-19.

Komine, H., 2010. Predicting hydraulic conductivity of sand bentonite mixture backfill before and after swelling deformation for underground disposal of radioactive wastes. Engineering Geology.

Kröhn, K. P., 2003a. New conceptual models for the resaturation of bentonite. Applied Clay Science 23 (1-4), 25-33.

Kröhn, K. P., 2003b. Results and interpretation of bentonite resaturation experiments with liquid water and water vapour. In: Schanz, T. (Ed.), Proceedings of the International Conference from Experimental Evidence towards Numerical Modeling of Unsaturated Soils, Weimar, Germany, vol. 1. Springer, Berlin, pp. 257-272.

Krohn, K, 2004, Report GRS-199, Modelling the Re-Saturation of Bentonite in Final Repositories in Crystalline Rock, ISBN 3-931995-66-6 
Lemaire, T., Moyne, C., Stemmelen, D., 2004. Imbibition test in a clay powder (MX-80 bentonite. Applied Clay Science 26: 235-248.

Lloret, A., Villar, M.V., Sanchez, M., Gens, A.., 2003. Mechanical behaviour of heavily compacted bentonite under high suction changes. Géotechnique, 53(1):27-40.

Loiseau, C., Cui, Y.J., Delage, P., 2002. The gradient effect on the water flow through a compacted swelling soil. Proc. 3rd Int Conf Unsaturated Soils, UNSAT'2002 Recife, Brazil, Balkema, vol. 1, pp. 395-400.

Lutz, J.F., Kemper, W.D., 1959. Intrinsic permeability of clay as afftected by clay-water interaction. Soil science 88: 83-90.

Marcial, D., 2003. Comportement hydromécanique et microstructural des mate'riaux de barrie're ouvrage'e. Ph.D. thesis, E' cole nationale des ponts et chausse'es, Paris, France

Miller, R.J., Low, P.F., 1963. Threshold Gradient for Water Flow in Clay Systems. Soil Science Society of America Journal. 27 (6):605-609.

Pusch, R., 1979. Highly compacted sodium bentonite for isolating rock-deposited radioactive waste products. Nucl. Technol. (United States), 45(2).

Pusch, R., 1999. Microstructural evolution of buffers. Engineering geology. 54:33-41.

Pusch, R., Yong, R., 2003. Water saturation and retention of hydrophilic clay buffer-microstructural aspects.Applied Clay Science, 23:61-68.

Saiyouri, N., Hicher, P.Y., Tessier, D., 2000. Microstructural approach and transfer water modeling in highly compacted unsaturated swelling clays. Mechanics of Cohesivefrictional Materials 5, 41-60.

Stepkowska, E.T.: Aspects of the clay electrolyte water-system with special reference to the geotechnical properties of clays. Eng. Geol. 28(3-4), 249-267 (1990)

Stroes-Gascoyne, S., 2010. Microbial occurrence in bentonite-based buffer, backfill and sealing materials from large-scale experiments at AECL's underground research laboratory. Applied Clay Science, 47(1-2):36-42.

Tang, A. M. \& Cui, Y. J., 2005. Controlling suction by the vapour equilibrium technique at different temperatures and its application in determining the water retention properties of MX80 clay. Can. Geotech. J. 42 (1): 287-296.

Tang, C.S., Tang, A..M., Cui, Y.J., Delage, P., Barnichon, J.D., Shi, B., 2011. A study of the hydro-mechanical behaviour of compacted crushed argillite. Engineering Geology. 118 (3-4):93-103.

Thomas, H.R., Cleall, P.J., Chandler, N., Dixon, D., Mitchell, H.P., 2003. Water infiltration into a large-scale in-situ experiment in an underground research laboratory. Geotechnique 53, 207-224.

Van Genuchten, M.T., 1980. A closed-form equation for predicting the hydraulic conductivity of unsaturated soils. Soil Science Society of America Journal, 44: 892-898.

Villar, M.V.; Romero, E. \& Lloret, A. 2005. Thermo-mechanical and geochemical effects on the permeability of high-density clays. In: Alonso, E.E. \& Ledesma, A.(eds.) Advances in understanding engineered clay barriers. A.A. Balkema Publishers, Leiden: 177-191.

Villar, M.V., Lloret, A.., 2008. Influence of dry density and water content on the swelling of a compacted bentonite. Applied Clay Science, 39(1-2):38-49.

Villar, M.V., Gómez-Espina, R. Campos, R., Barrios, I. \& Gutiérrez-Nebot, L. 2012. Porosity Changes Due To Hydration Of Compacted Bentonite. In: Mancuso, C.; Jommi, C. \& 
D'Onza, F. (Eds.): Unsaturated Soils: Research and Applications, Volume 1, pp. 137-144. Springer, Berlin.

Wang, Q., Tang, A. M., Cui, Y. J., Delage, P., Gatmiri. B., 2012. Experimental study on the swelling behaviour of bentonite/claystone mixture. Engineering Geology. 124:59-66.

Wang, Q., Tang, A.M., Cui, Y.J., Barnichon, J.D. Delagen P., Ye, W.M., 2013. Voids effects on the hydro-mechanical behaviour of compacted bentonite-sand mixture. Soils and Foundations 53(2), 232-245.

Ye, W.M., Cui, Y.J., Qian, L.X., Chen. B., 2009. An experimental study of the water transfer thro ugh confined compacted GMZ bentonite. Engineering Geology, 108(3-4):169-176.

Yong, R.N., Warkentin, B.P., 1975. Soil properties and behaviour. Elsevier, Amsterdam.

Yong, R.N., Boonsinsuk, P., and Wong, G., 1986. Formulation of backfill material for a nuclear fuel waste disposal vault. Canadian Geotechnical Journal, 23(2):216-228.

Zou, Y., 1996. A non-linear permeability relation depending on the activation energy of pore liquid. Géotechnique 46 (4), 769-774. 


\section{List of Tables}

633

Table 1. Chemical composition of the synthetic water

Table 2. Tests performed for water retention property and microstructure observation

\section{List of Figures}

639

Figure 1. Grain size distribution of the MX80 bentonite and sand

Figure 2. Schematic setup of the infiltration cell

642

643

644

645

646

647

648

649

650

651

652

653

654

655

656

657

658

659

660

661

662

663

664

665

666

Figure 3. Constant volume cell for WRC determination; (a) osmotic method; (b) vapour equilibrium technique

Figure 4. WRCs of bentonite/sand mixture under constant-volume conditions

Figure 5 Water content and dry density distributions after dismantling of the sample

Figure 6. Evolution of relative humidity during water infiltration

Figure 7. Suction profiles at different times

Figure 8. Determination of hydraulic gradient and water flux: (a) hydraulic gradient; (b) rate of water flow

Figure 9. Calculated and measured water volume into the sample

Figure 10. Hydraulic conductivity versus suction for different measurement sections

Figure 11. Pore size distributions of the bentonite-sand mixture wetted with different suctions under constant volume conditions

Figure 12. SEM photographs of bentonite/sand mixture samples equilibrated at different suctions

Figure 13. Water flux versus hydraulic gradient for different suctions

Figure 14. Hydraulic conductivity versus suction

Figure 15. Changes of large-pore void ratio with suction

(1)

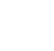


Table 1. Chemical composition of the synthetic water

\begin{tabular}{lccccccc}
\hline $\begin{array}{l}\text { Components } \\
\text { Mass (g) per litre of } \\
\text { solution }\end{array}$ & $\mathrm{NaHCO}_{3}$ & $\mathrm{Na}_{2} \mathrm{SO}_{4}$ & $\mathrm{NaCl}$ & $\mathrm{KCl}$ & $\mathrm{CaCl}_{2} \cdot 2 \mathrm{H}_{2} \mathrm{O}$ & $\mathrm{MgCl}_{2} \cdot 6 \mathrm{H}_{2} \mathrm{O}$ & $\mathrm{SrCl}_{2} \cdot 6 \mathrm{H}_{2} \mathrm{O}$ \\
\hline
\end{tabular}

668

669 Table 2. Tests performed for water retention property and microstructure observation

\begin{tabular}{cccc}
\hline Suction & Suction control & \multicolumn{2}{c}{ Microstructure } \\
$(\mathrm{MPa})$ & method and duration & MIP & SEM \\
\hline 38 & & $\sqrt{ }$ & $\sqrt{ }$ \\
24.9 & Vapour & $\sqrt{ }$ & \\
12.6 & $(2$ months) & $\sqrt{ }$ & \\
9.0 & & $\sqrt{ }$ & $\sqrt{ }$ \\
4.2 & & $\sqrt{ }$ & \\
\hline 1 & Osmotic & & \\
0.1 & (2 months) & & $\sqrt{ }$ \\
\hline 0 & Distilled water & $\sqrt{ }$ & $\sqrt{ }$ \\
65 & (2 months) & $\sqrt{ }$ & $\sqrt{ }$ \\
\hline
\end{tabular}

670

671

672

673

674 


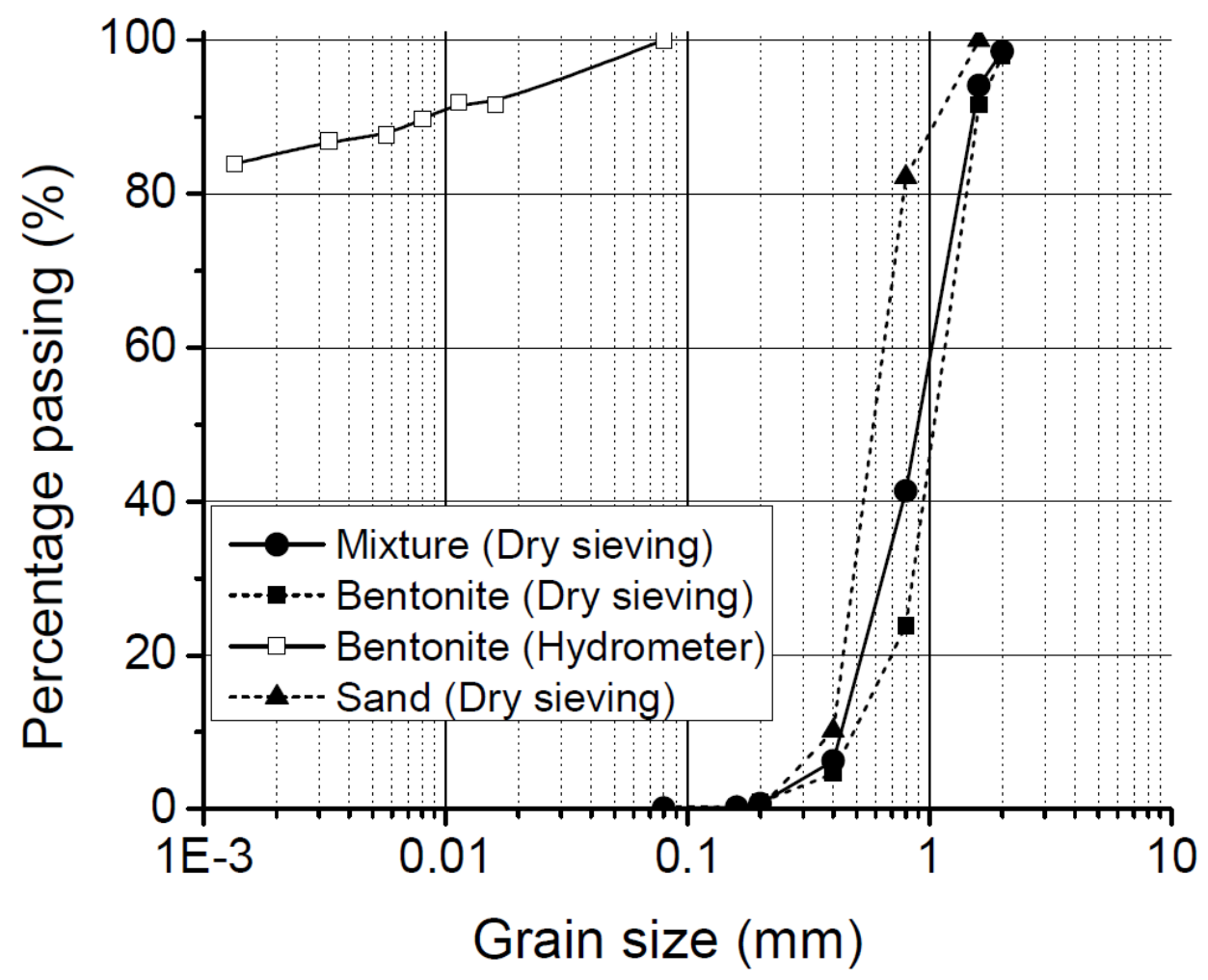

676 Figure 1. Grain size distribution of the MX80 bentonite and sand

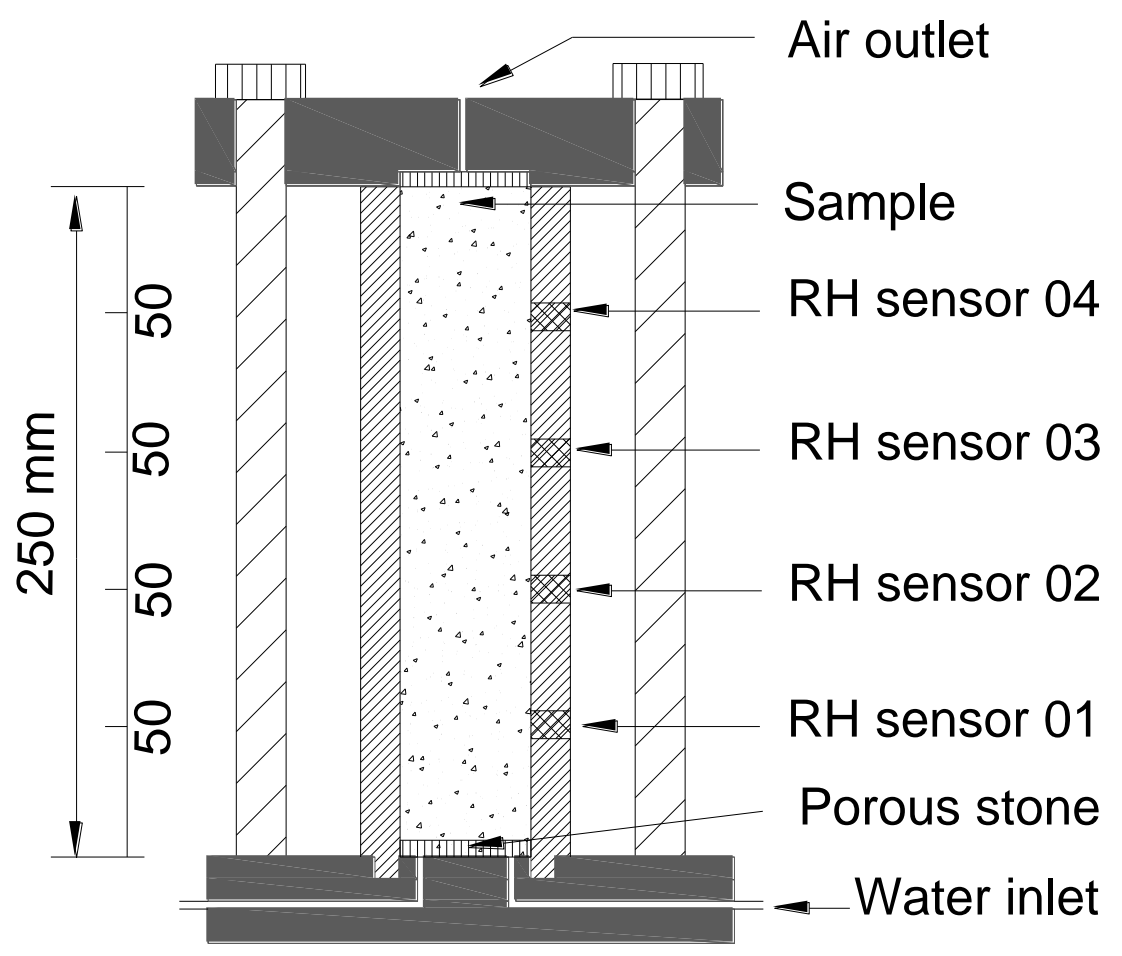

Figure 2. Schematic setup of the infiltration cell 
679

680

681

682

683 Figure 3. Constant volume cell for WRC determination; (a) osmotic method (controlling of 684 matric suction); (b) vapour equilibrium technique (controlling of total suction)

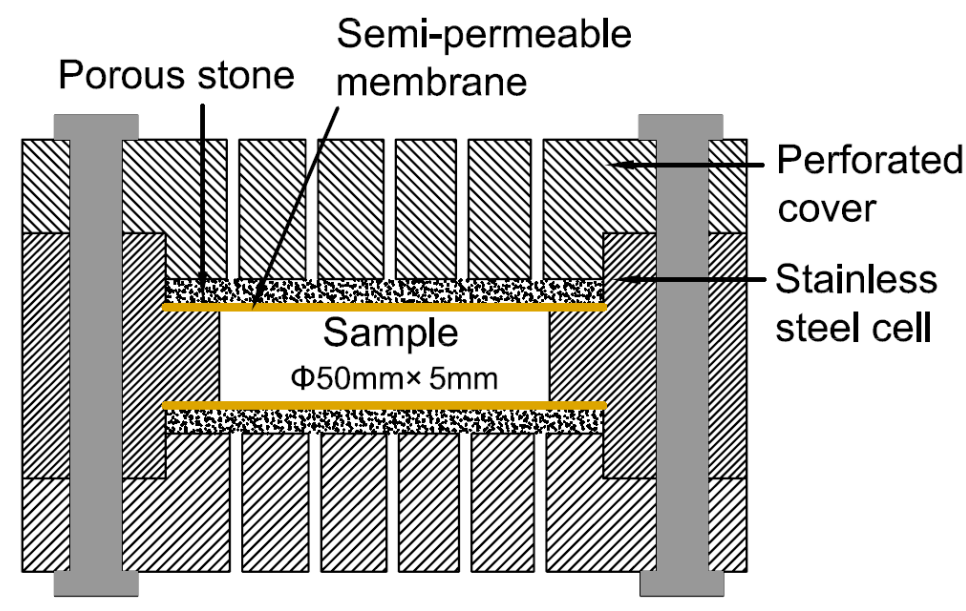

(a)

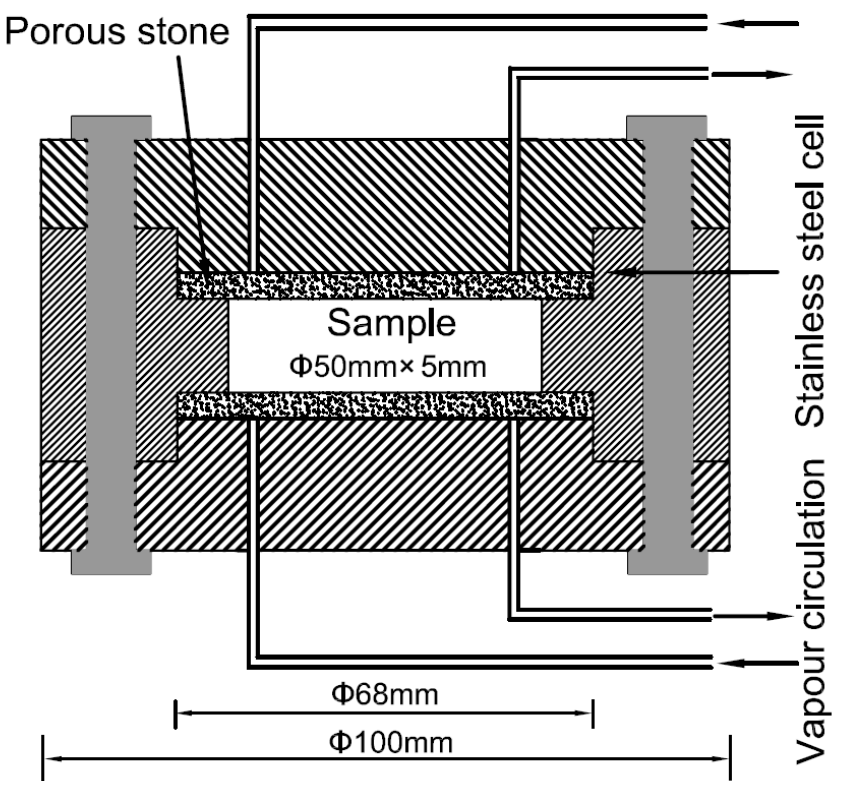

(b) 


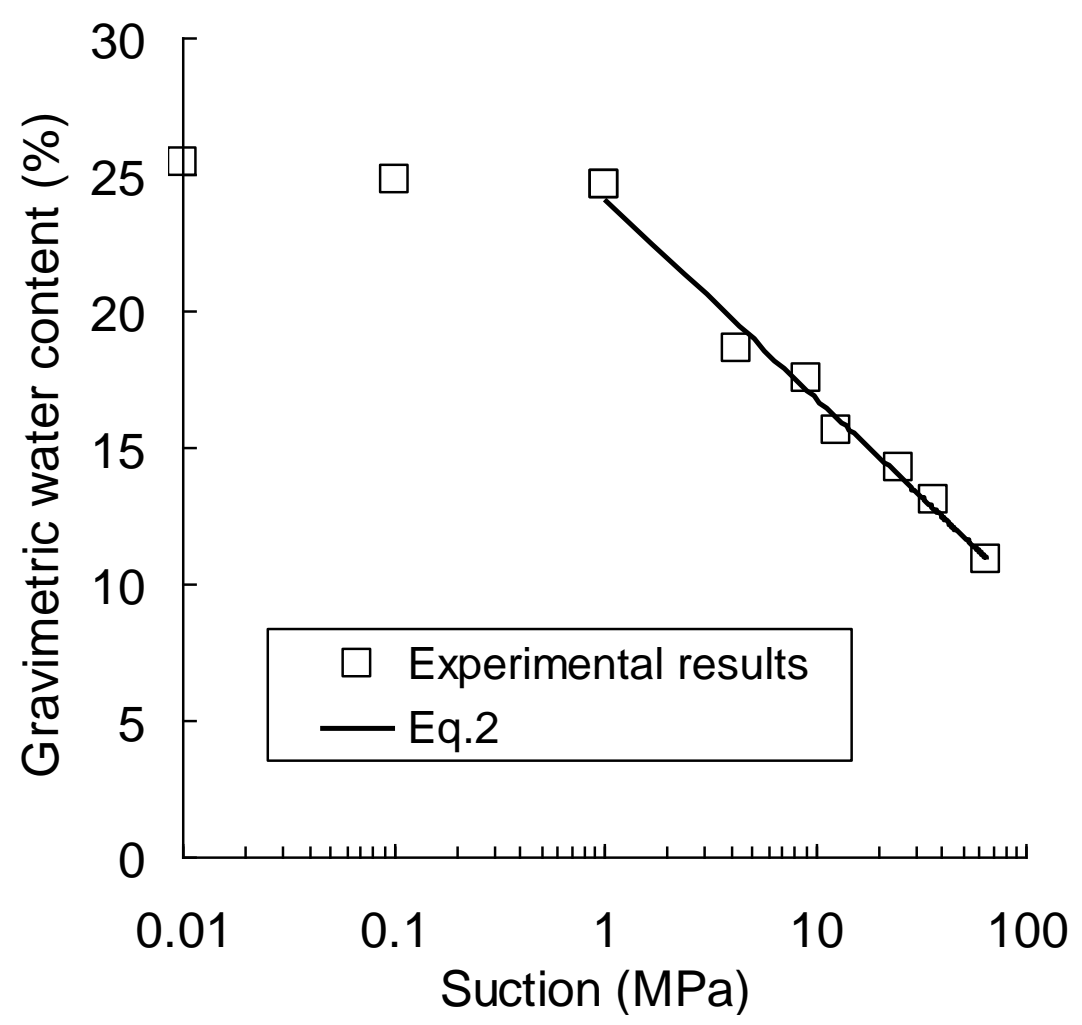

686 Figure 4. WRC of bentonite/sand mixture under constant-volume conditions

687 


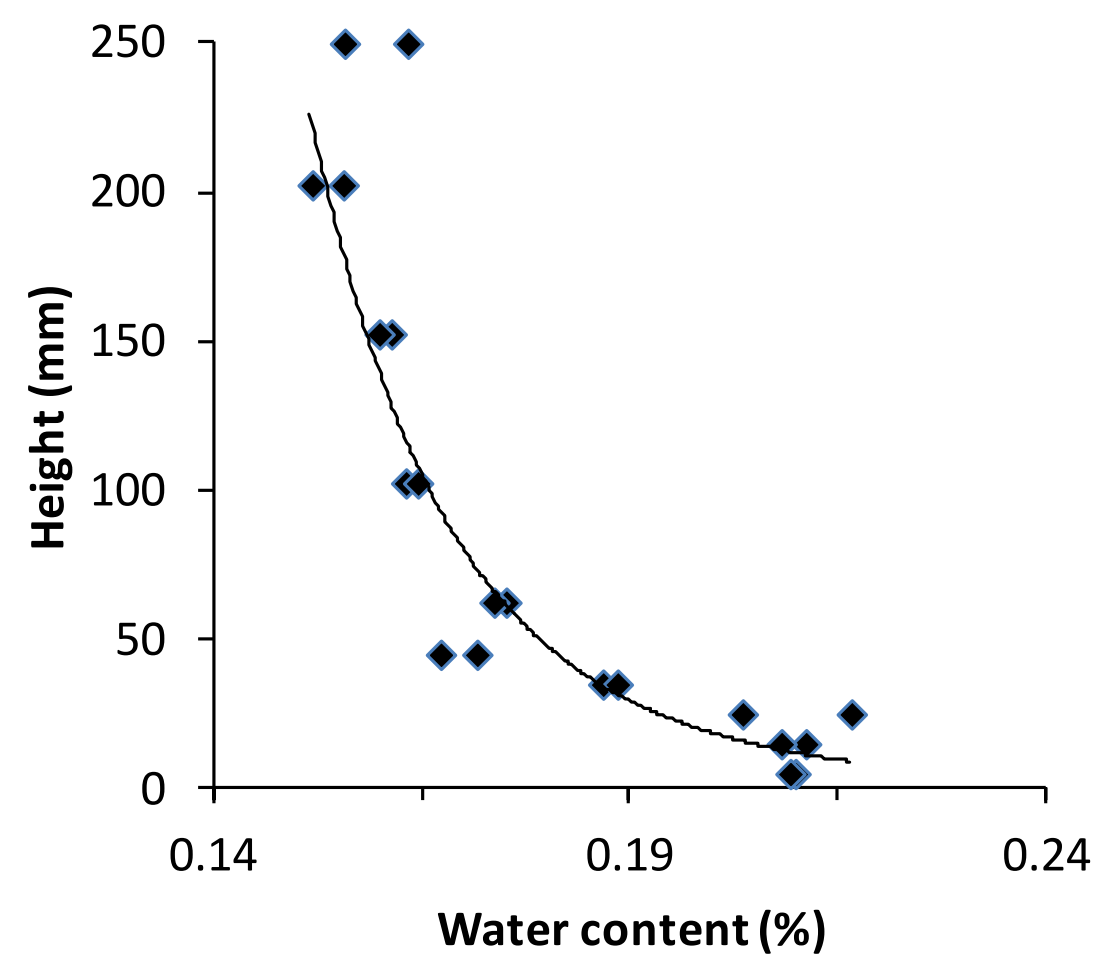

689

(a) water content distribution

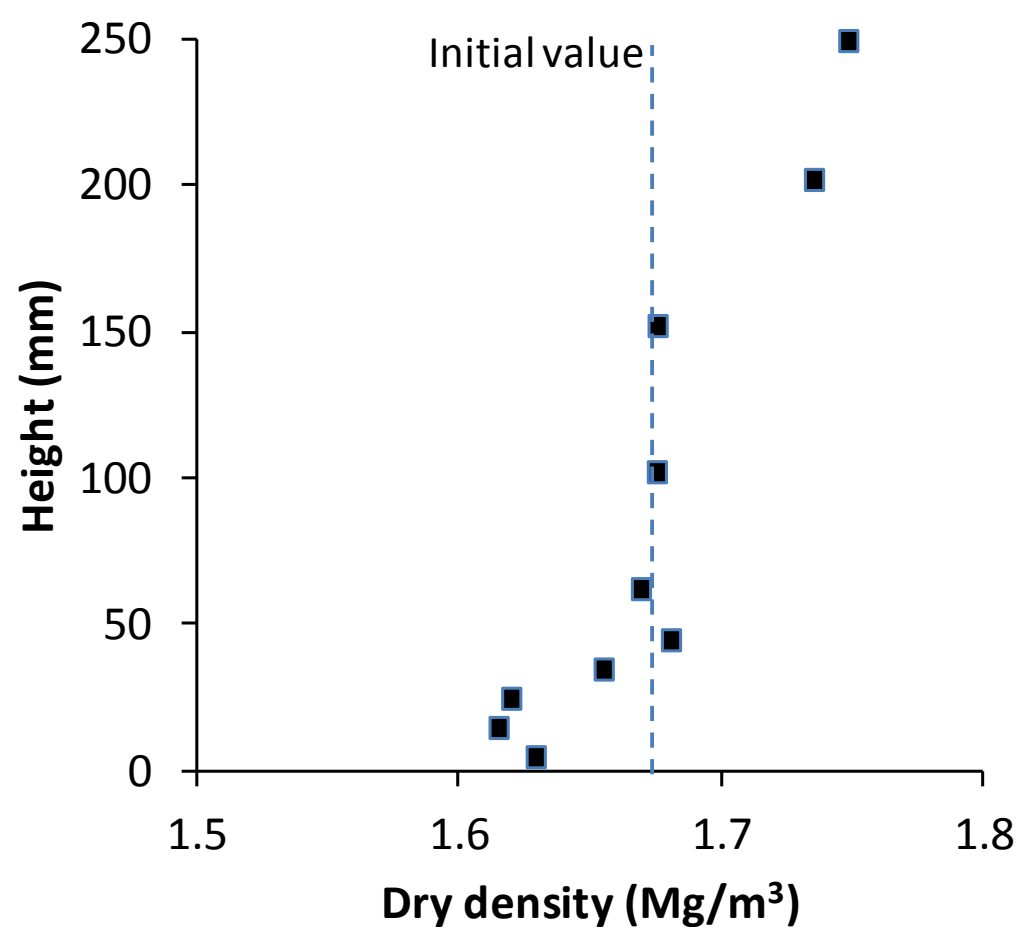

691

(b) dry density distribution

692 Figure 5 Water content and dry density distributions after dismantling of the sample 693 


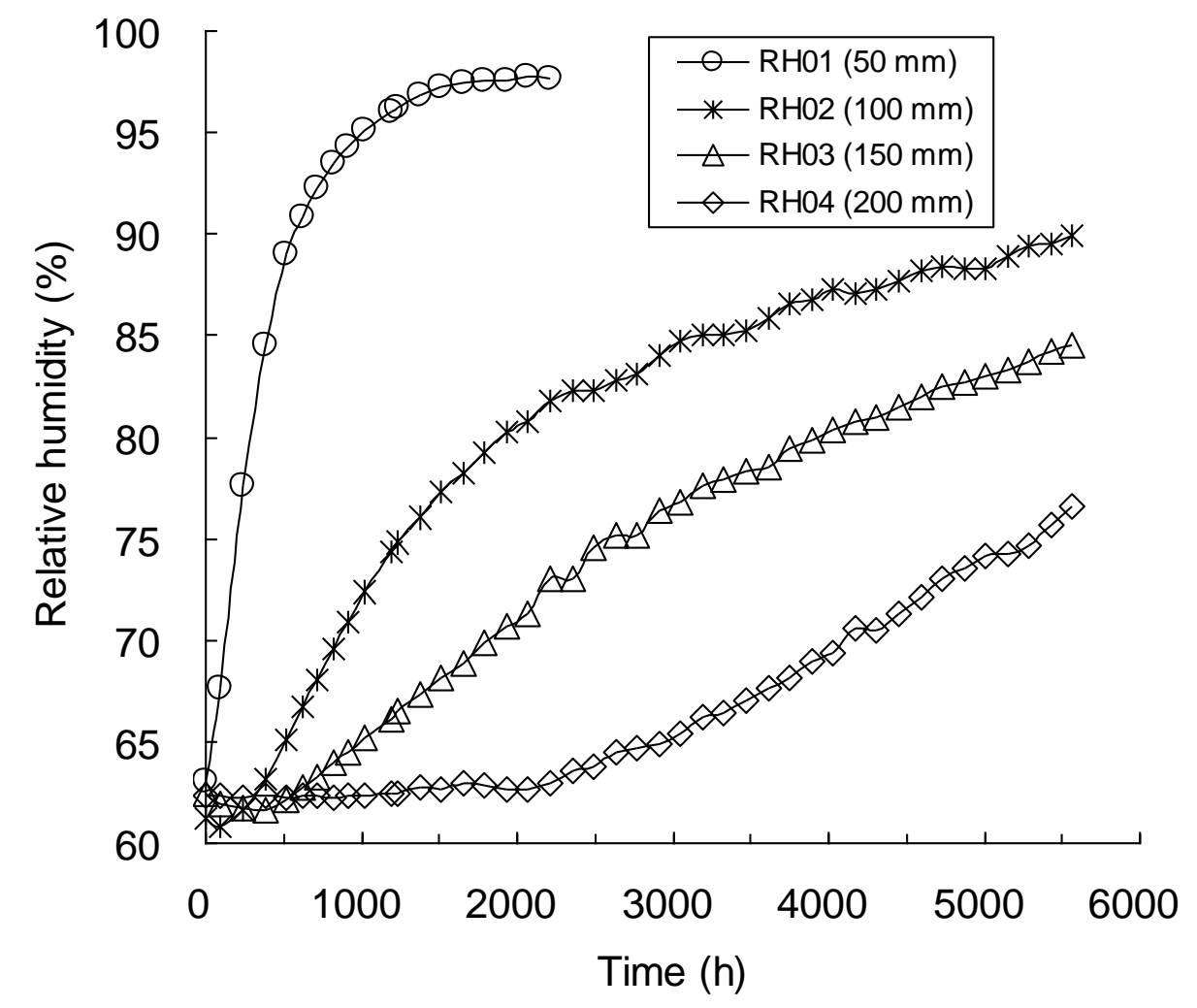

695 Figure 6. Evolution of relative humidity during water infiltration

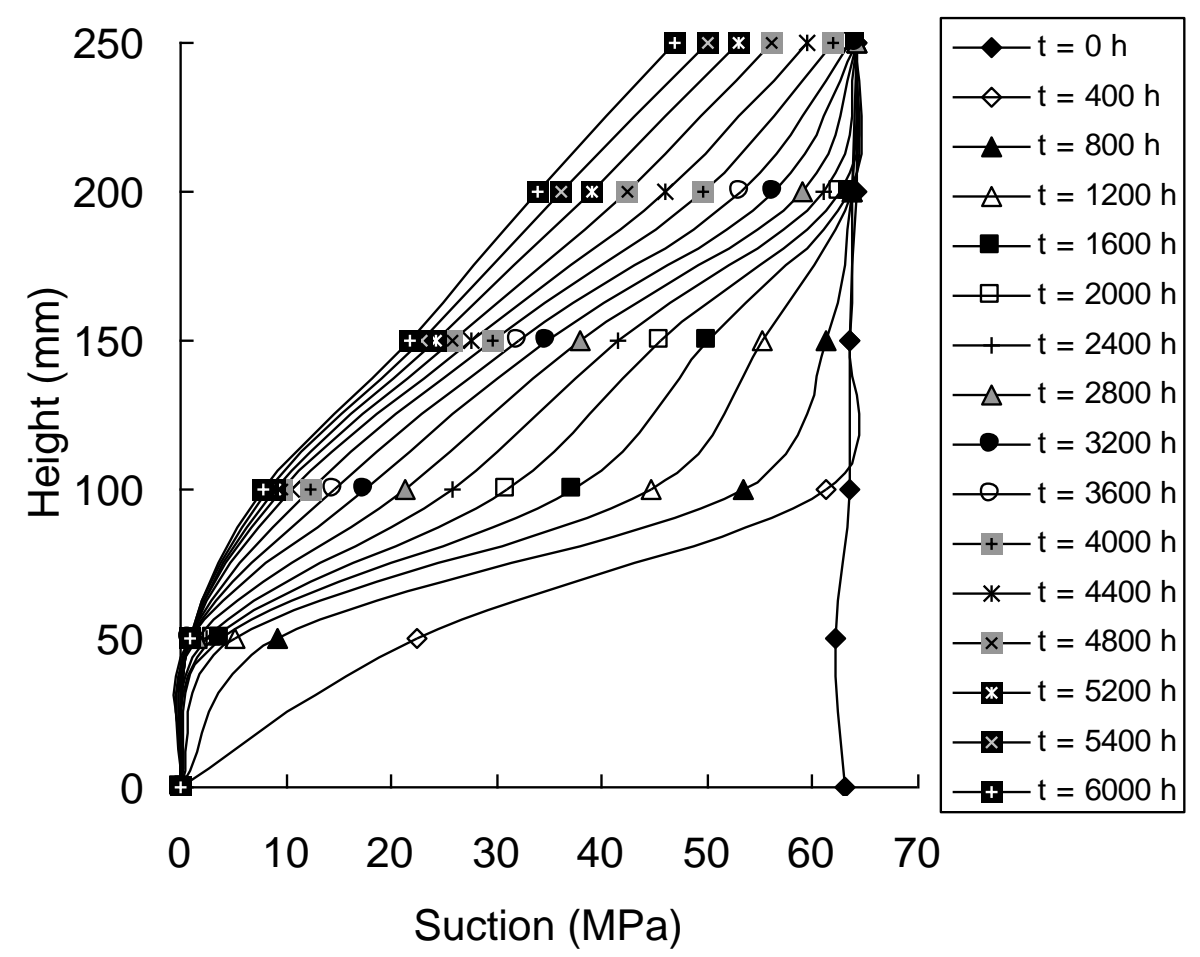

Figure 7. Suction profiles at different times (Note: There were no measurements at height $250 \mathrm{~mm}$.

698 The values plotted in the figure were extrapolated from the measurements at lower heights) 


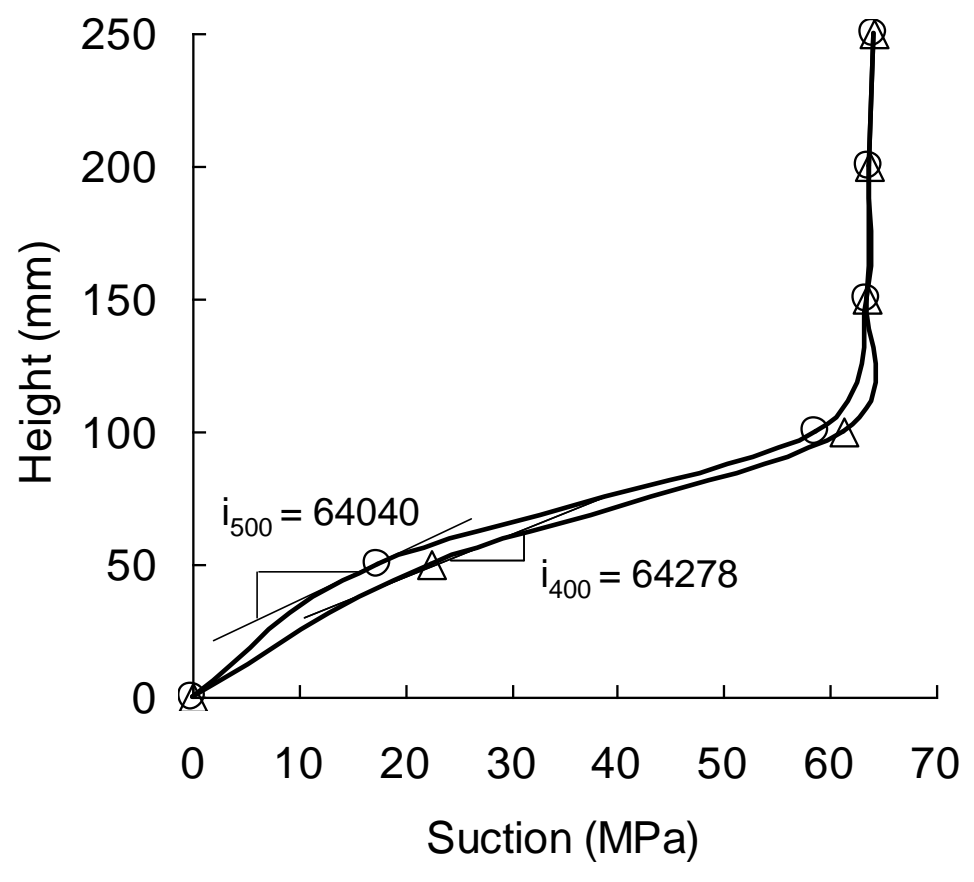

701

(a)

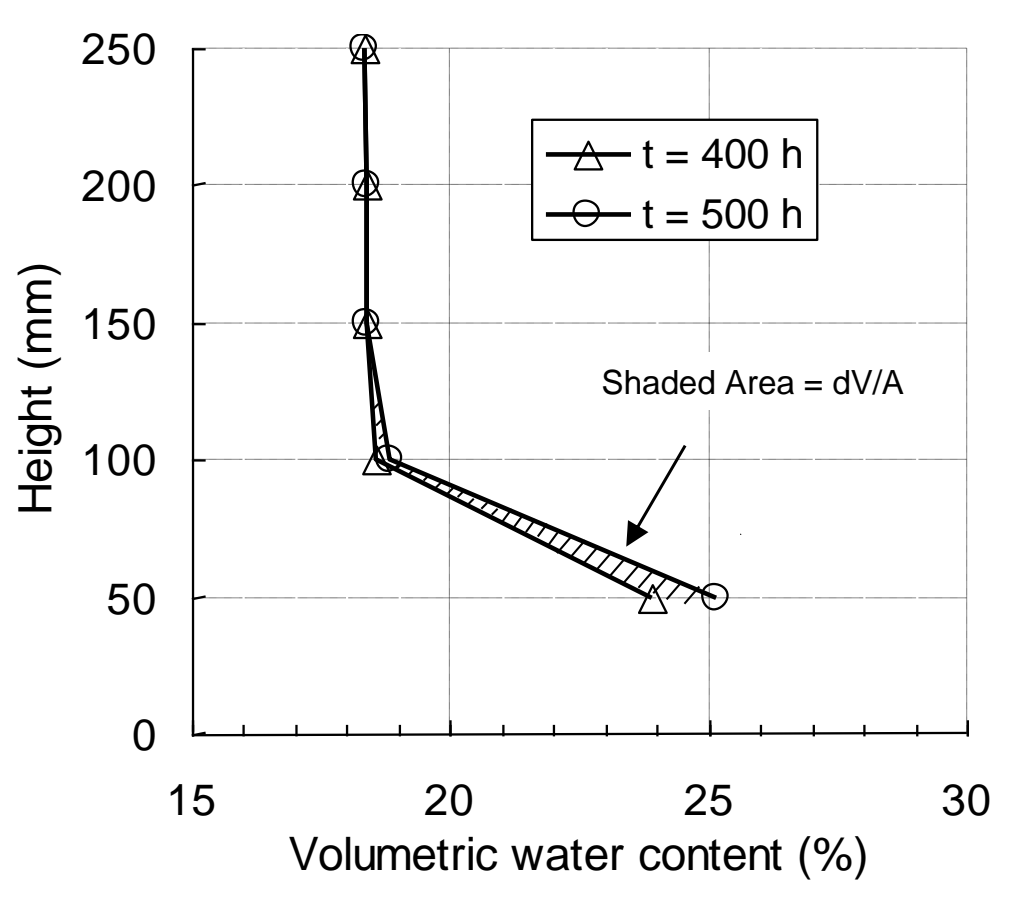

703

(b)

704 Figure 8. Determination of hydraulic gradient and water flux for two times (400 and $500 \mathrm{~h}$ )

705 during infiltration: (a) hydraulic gradient; (b) rate of water flow 


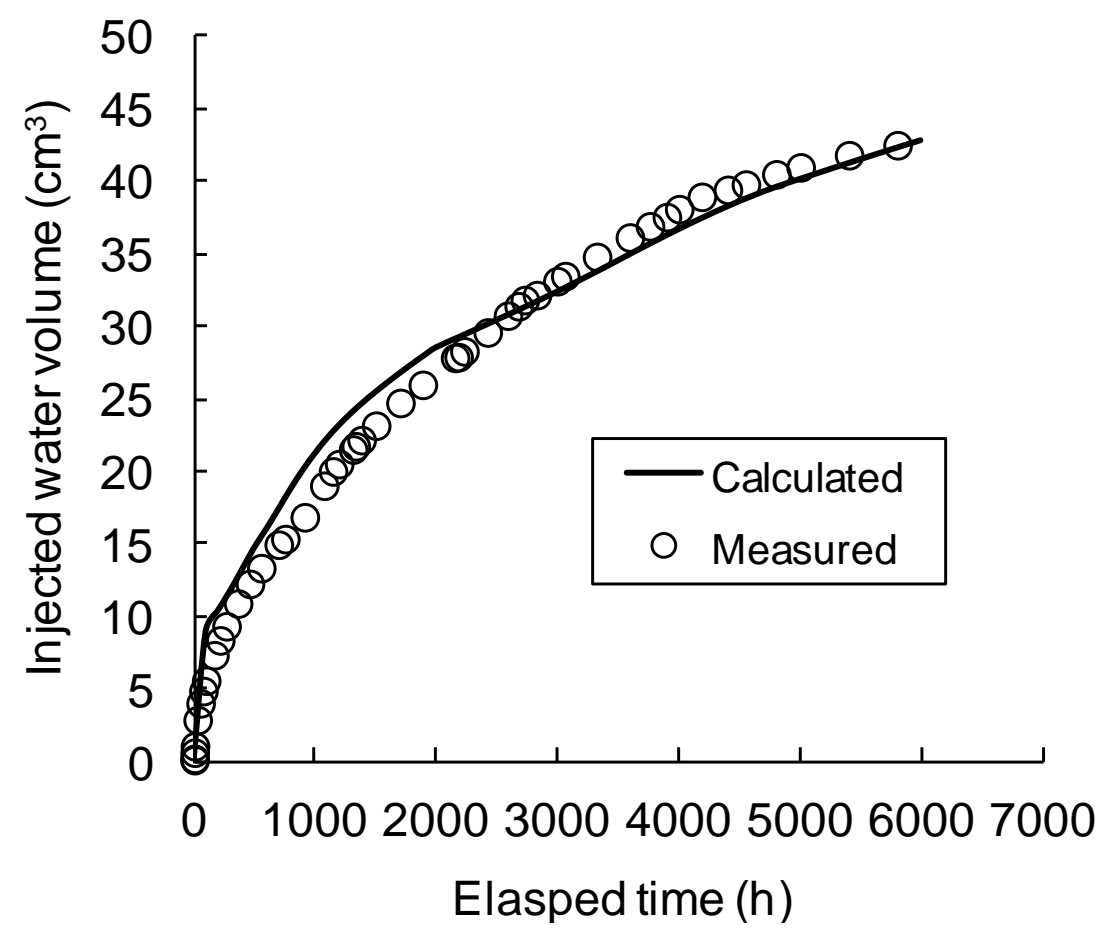

Figure 9. Calculated and measured water volume into the sample

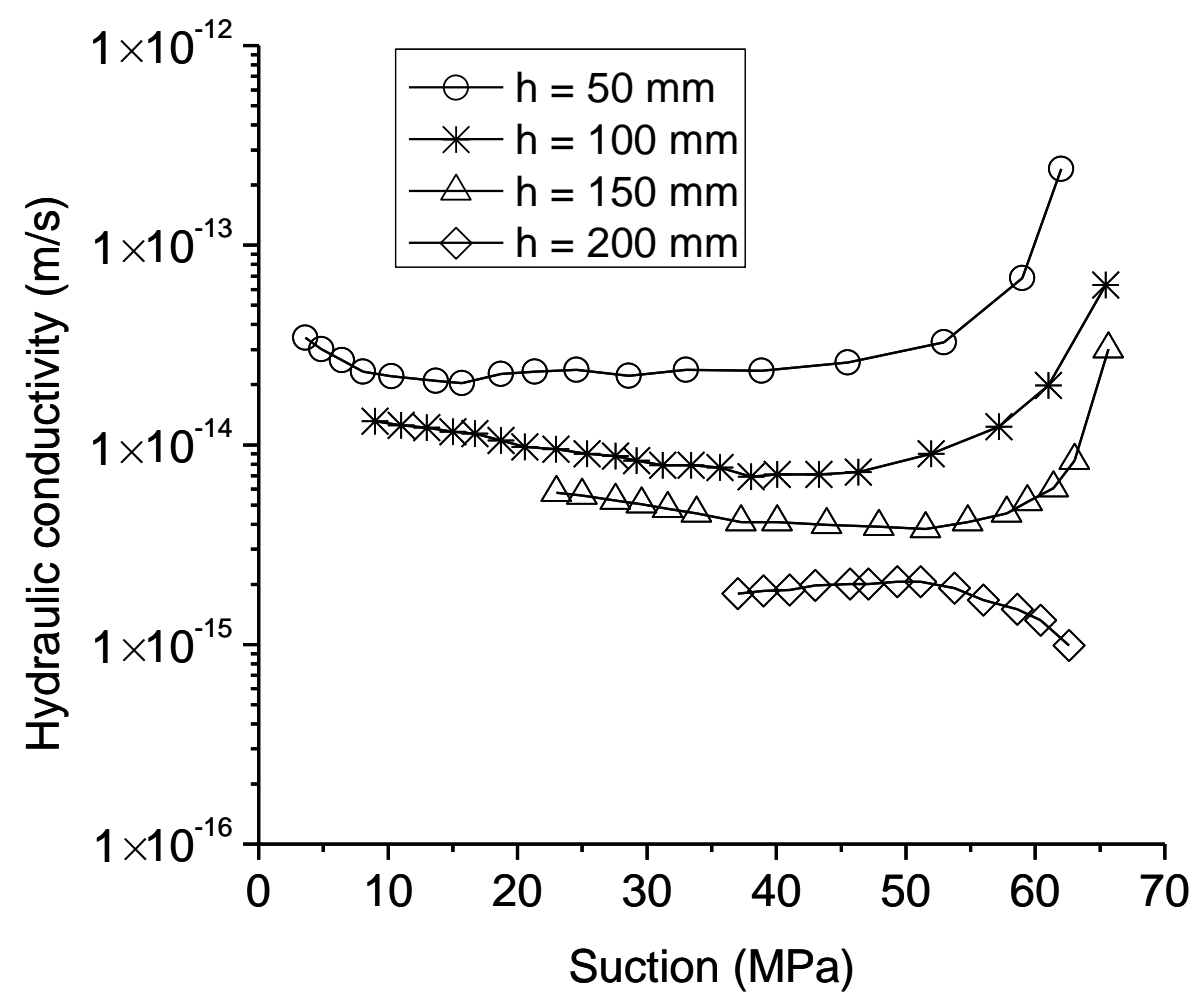

710 Figure 10. Hydraulic conductivity versus suction for different measurement sections ("h" 711 represents the distance from hydration surface 


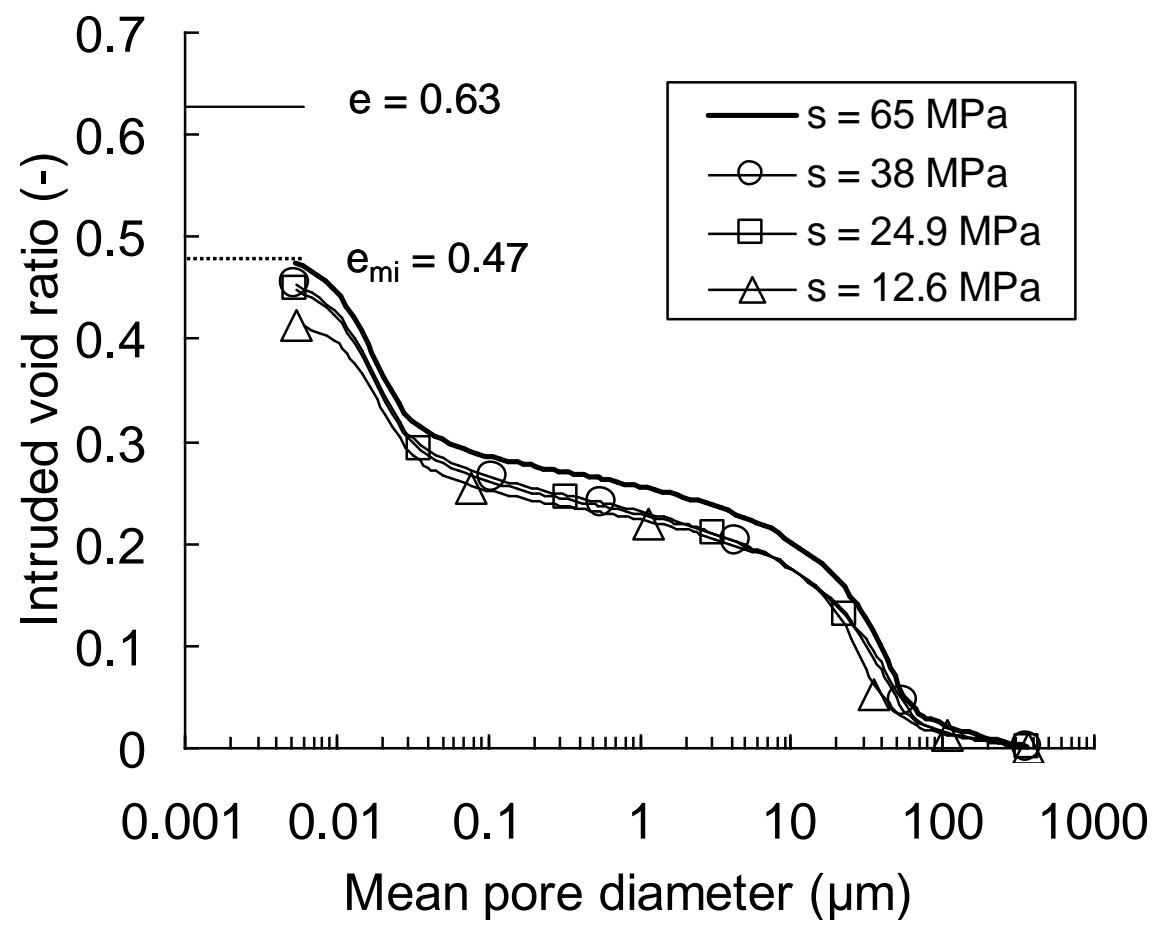

(a) 65 - 12.6 MPa suction

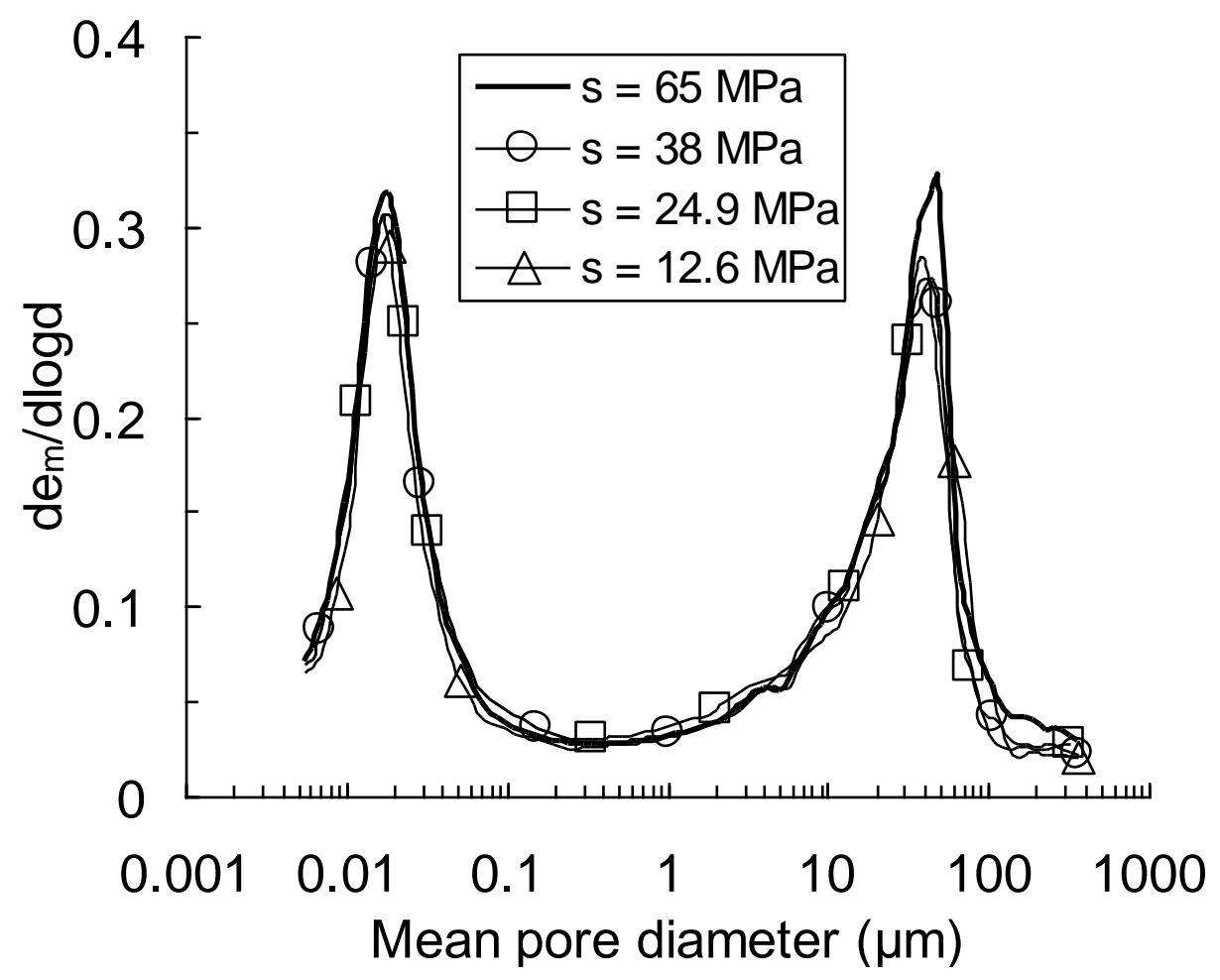




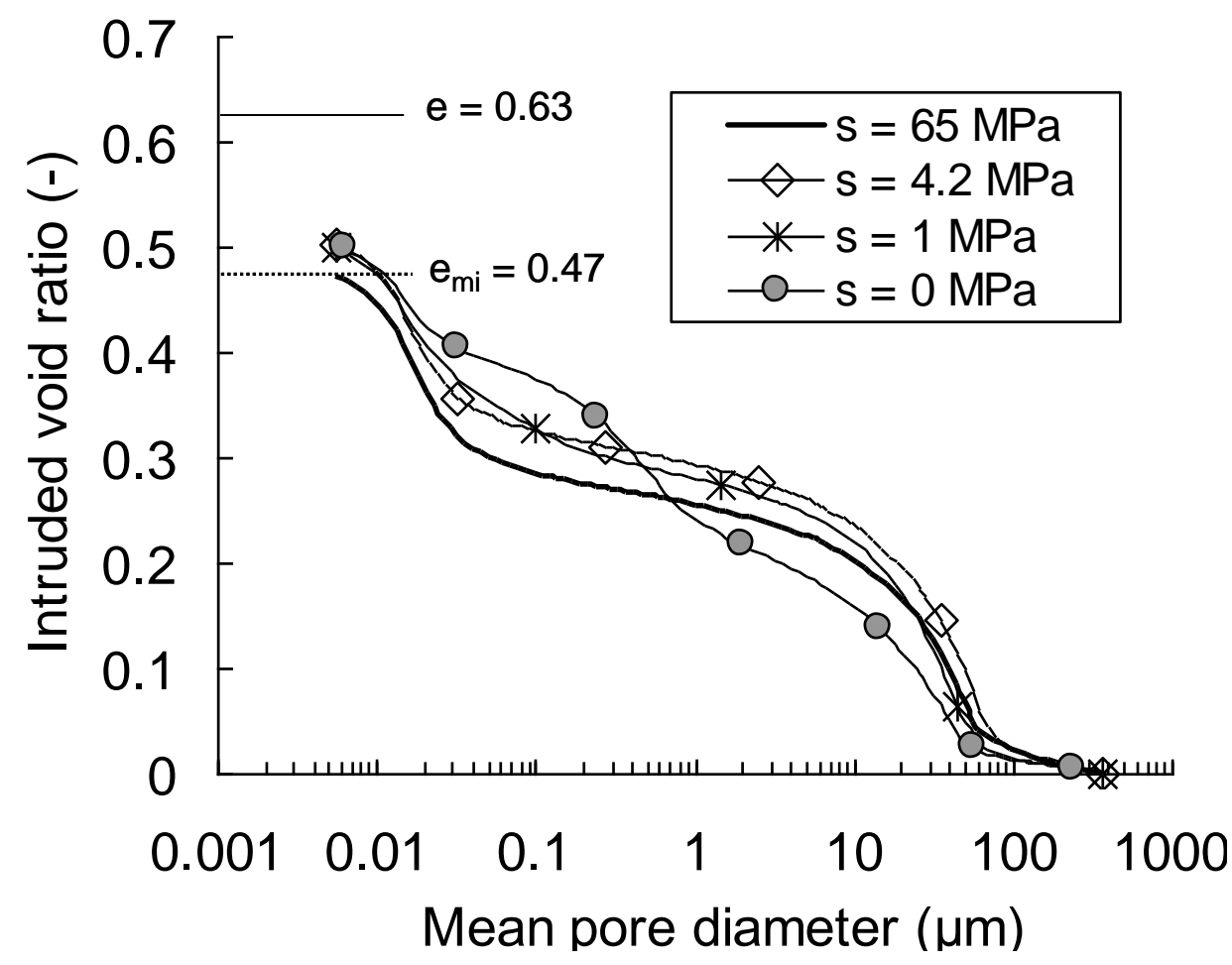

(c) 4.2-0 MPa suction

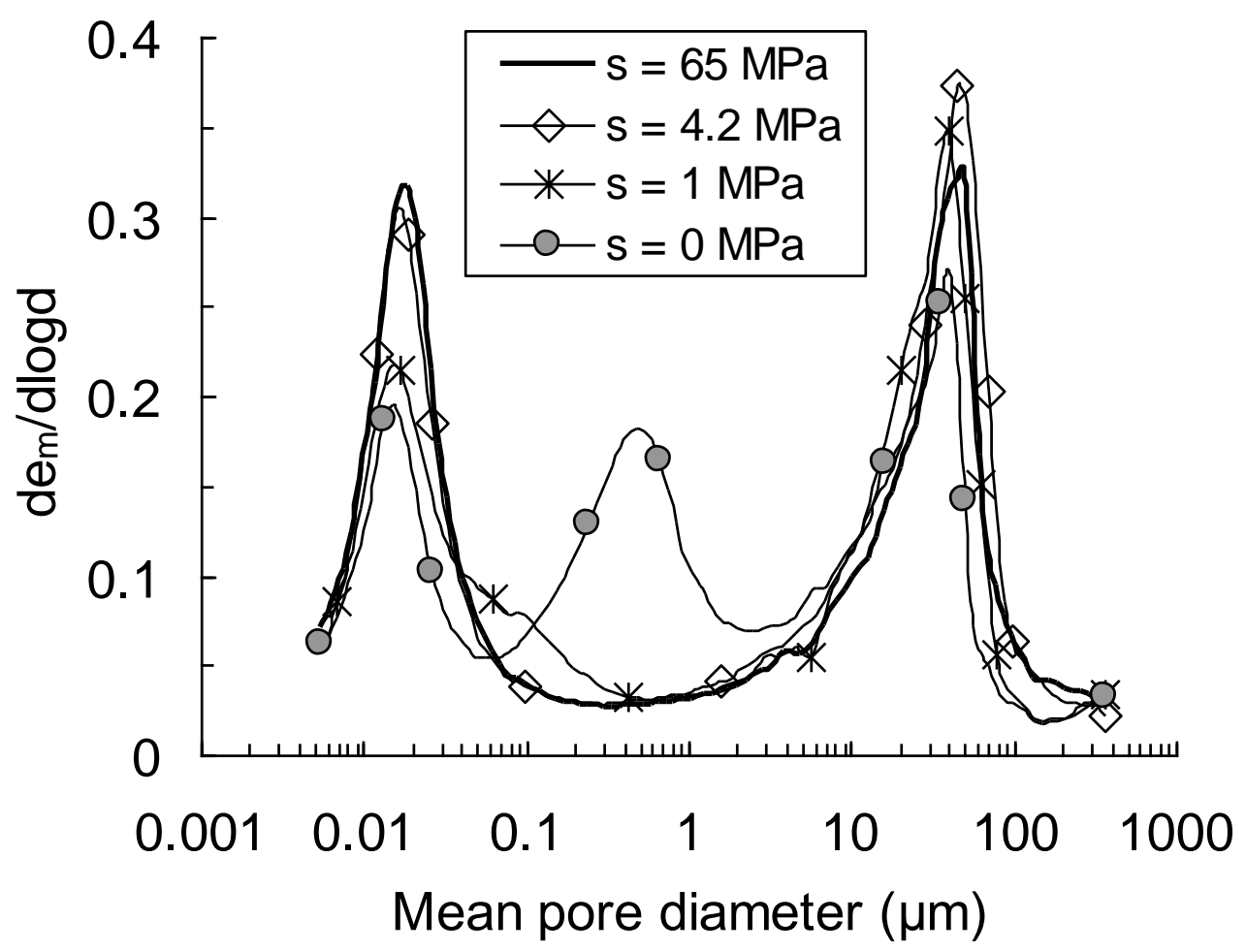

(d) 4.2 - 0 MPa suction

Note: symbols plotted in the figure do not correspond to all the measurement points, just a few symbols in each curve are plotted for distinction.

Figure 11. Pore size distributions of the bentonite-sand mixture wetted with different suctions 


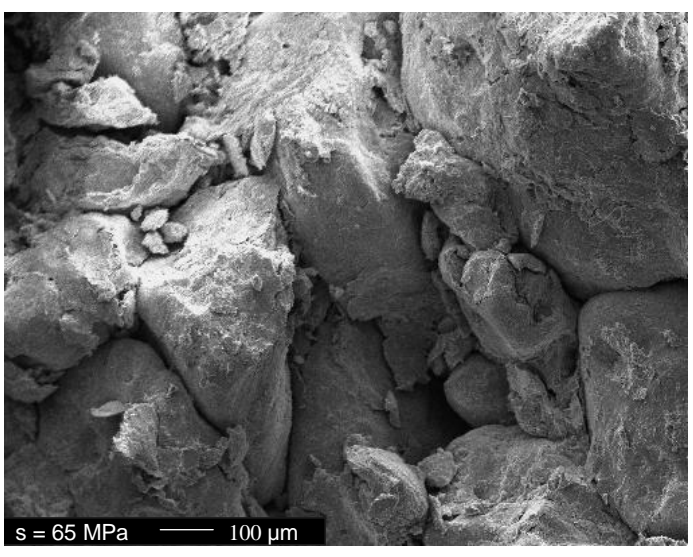

(a) $\mathrm{s}=65 \mathrm{MPa}(1250 \times 1000 \mu \mathrm{m})$

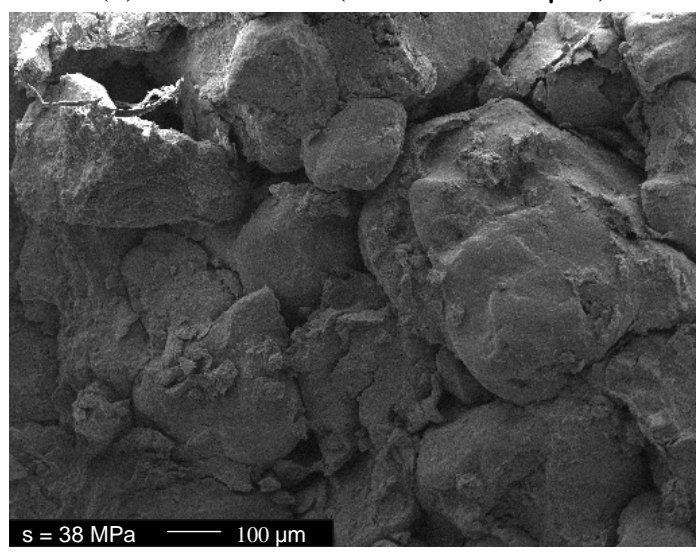

(c) $\mathrm{s}=38 \mathrm{MPa}(1250 \times 1000 \mu \mathrm{m})$

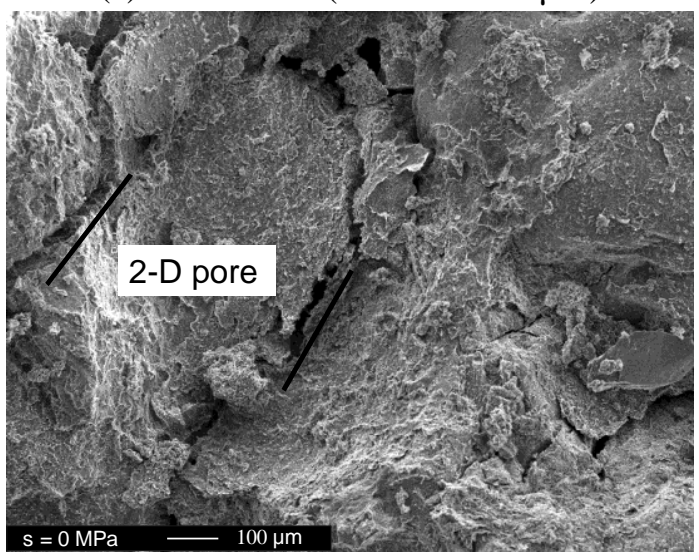

(e) $\mathrm{s}=0 \mathrm{MPa}(1250 \times 1000 \mu \mathrm{m})$

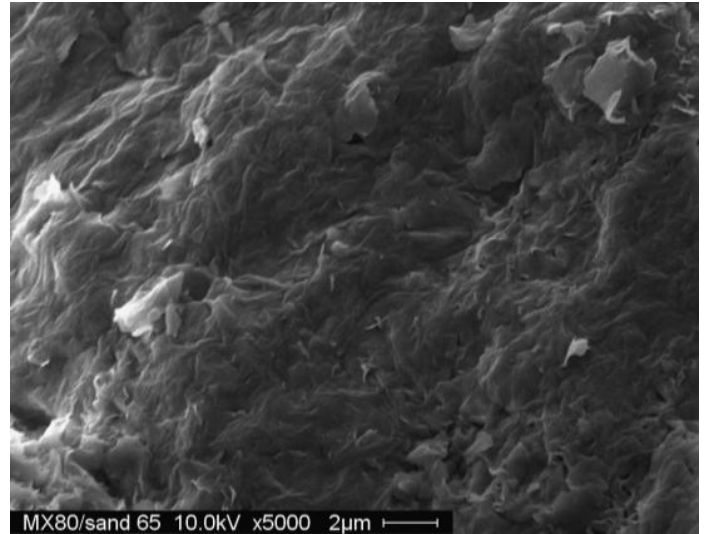

(b) $\mathrm{s}=65 \mathrm{MPa}(25 \times 20 \mu \mathrm{m})$

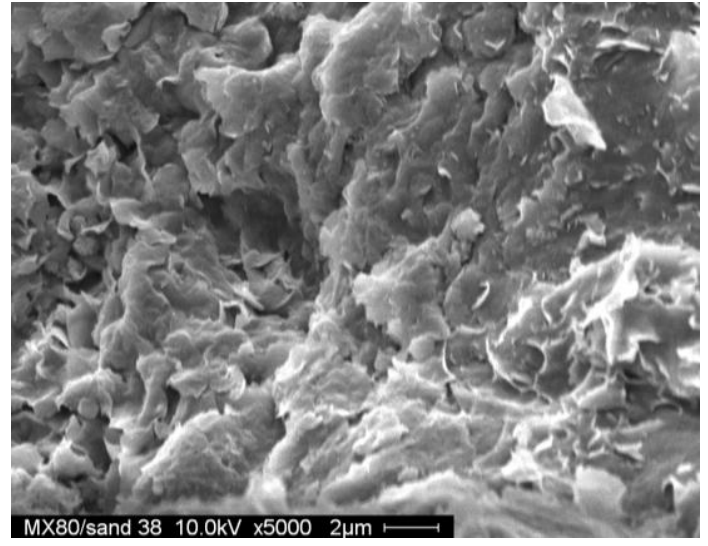

(d) $\mathrm{s}=38 \mathrm{MPa}(25 \times 20 \mu \mathrm{m})$

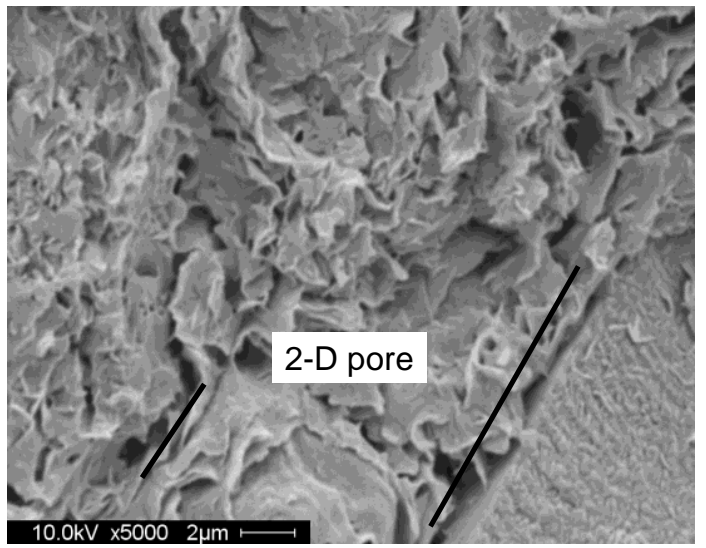

(f) $\mathrm{s}=0 \mathrm{MPa}(25 \times 20 \mu \mathrm{m})$

724 Figure 12. SEM photographs of bentonite/sand mixture samples equilibrated at different 725 suctions 


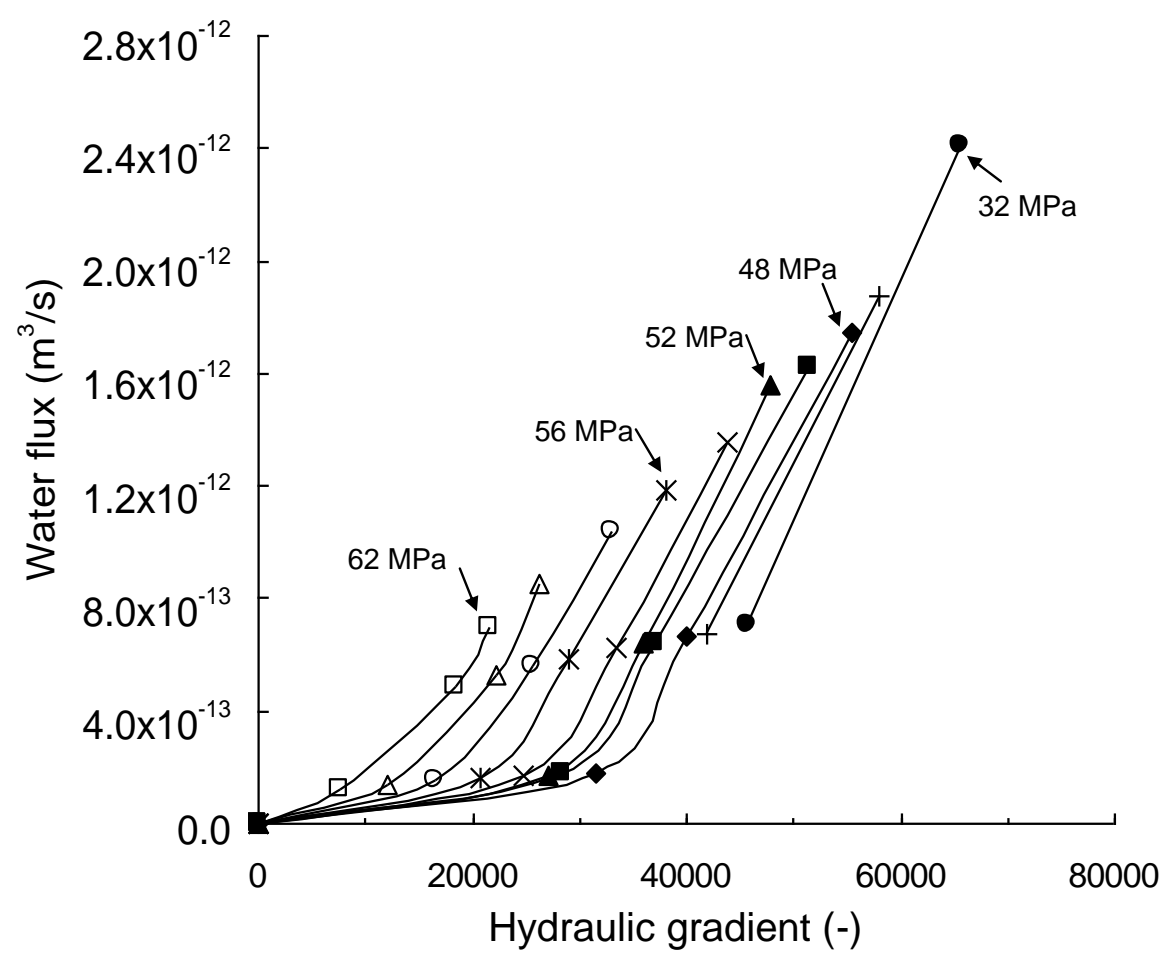

Figure 13. Water flux versus hydraulic gradient for different suctions

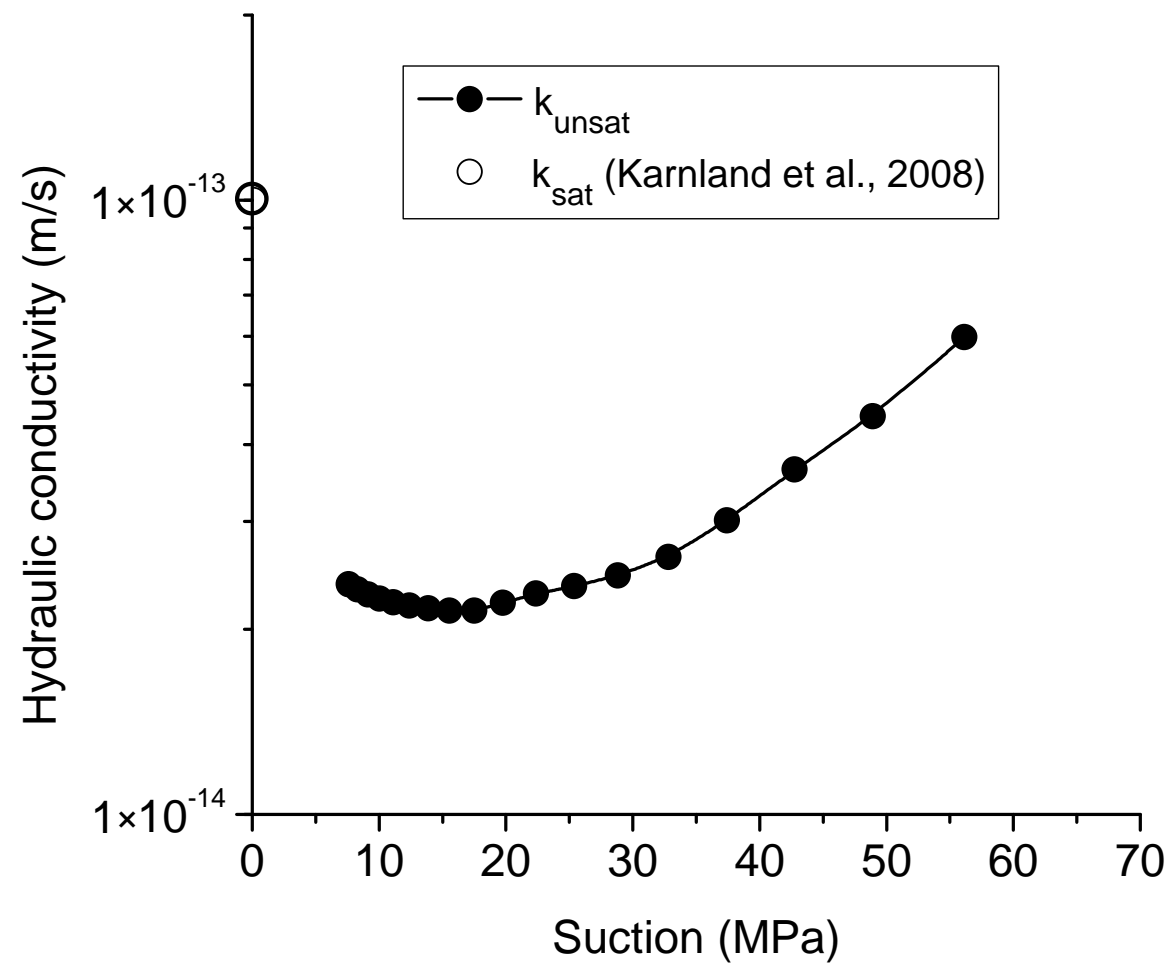

Figure 14. Hydraulic conductivity versus suction 


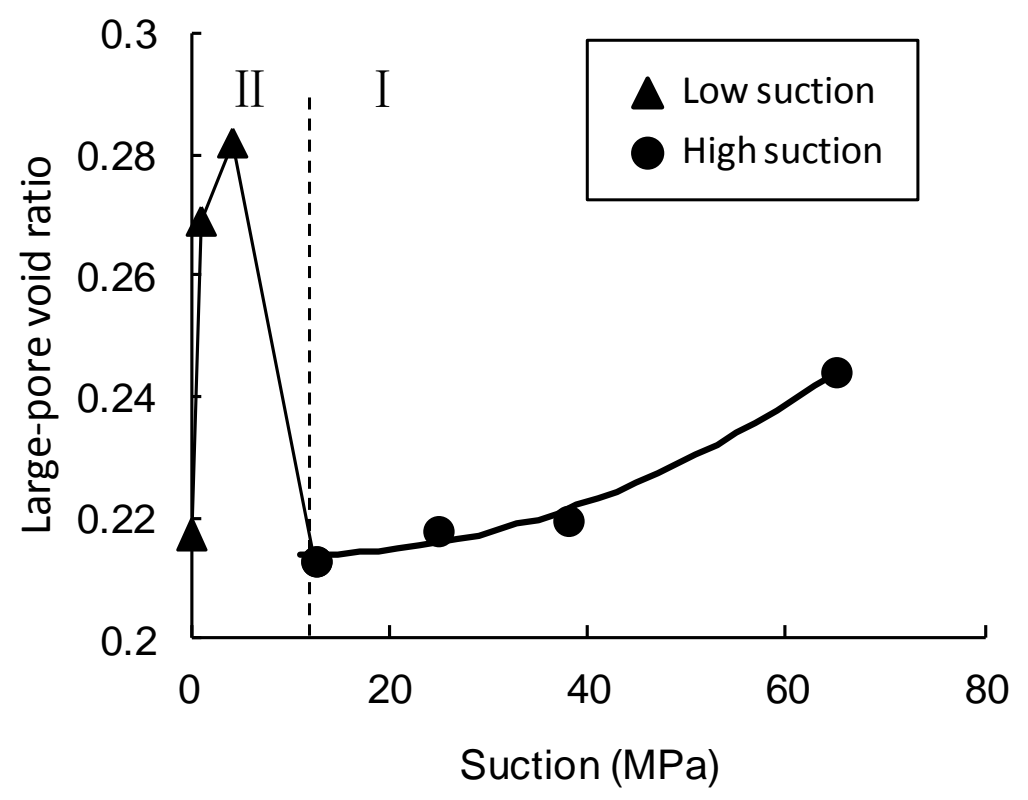

731 Figure 15. Changes of large-pores void ratio (diameter larger than $2 \mu \mathrm{m}$ ) with suction 